\title{
Diversity and distribution of Arctic Echinoderes species (Kinorhyncha: Cyclorhagida), with the description of one new species and a redescription of $E$. arlis Higgins, 1966
}

\author{
Katarzyna Grzelak ${ }^{1,2}$ (D) Martin V. Sørensen ${ }^{3}$ \\ Received: 13 November 2017 / Revised: 21 March 2018 / Accepted: 9 April 2018 / Published online: 4 May 2018 \\ (C) The Author(s) 2018
}

\begin{abstract}
The kinorhynch fauna from Svalbard and the Arctic Ocean north of Svalbard was explored, and a total of nine species of Echinoderes was identified. Two species were new to science, and one, Echinoderes balerioni sp. nov., is described. Echinoderes balerioni sp. nov. is characterized by the presence of short middorsal spines on segments 4 , 6 , and 8 , and in lateroventral positions on segments 6 to 9 . Tubes are present in laterodorsal, sublateral, and ventrolateral positions on segment 2 , lateroventral positions on segment 5 , and lateral accessory positions on segment 8 , and tergal extensions conspicuously long and spiniform. The collected material also offered the first chance to examine specimens of Echinoderes arlis with scanning electron microscopy, which prompted a redescription of the species. The recorded species are compared with all other known records of Echinoderes in the Arctic region, and the summarized data suggests that at least some species show a circumpolar distribution.
\end{abstract}

Keywords Meiobenthos $\cdot$ Meiofauna $\cdot$ Morphology $\cdot$ Svalbard $\cdot$ Taxonomy

\section{Introduction}

Kinorhynchs are meiofaunal organisms, occurring in a wide spectrum of marine habitats all over the world, from the shallow waters to the abyssal depths (e.g., Sørensen 2008; Neuhaus 2013; Herranz et al. 2014; Adrianov and Maiorova 2015; Yamasaki 2016a). Although their presence is frequently reported in a number of ecological meiofaunal studies,

This article is registered in ZooBank under urn:lsid:zoobank.org:pub: AEC03F05-E10F-4BAD-A4C4-9833BF089091

Communicated by S. Gollner

Katarzyna Grzelak

kgrzelak@iopan.pl

1 Laboratory of Polar Biology and Oceanobiology, Faculty of Biology and Environmental Protection, University of Łódź, 90-237 Łódź, Poland

2 Institute of Oceanology, Polish Academy of Sciences, 81-712 Sopot, Poland

3 Natural History Museum of Denmark, University of Copenhagen, 1350 Copenhagen, Denmark knowledge on their taxonomic composition and distribution is rather limited, since kinorhynch specimens are usually not identified to genus or species level. Currently recognized kinorhynch species may represent even less than $20 \%$ of the total estimated number of kinorhynch species (Appeltans et al. 2012).

Due to logistic difficulties associated with sampling in high latitudes and the scarcity of taxonomic expertise, diversity of Arctic kinorhynchs fauna is poorly known in contrast to other regions. Even though the first Arctic kinorhynch was described in the mid-60s (Echinoderes arlis Higgins, 1966), only 20 species were described so far from this geographic region (Grzelak and Sørensen 2018 and references therein). Hence, the Arctic represents a significant gap of knowledge about the biogeography and biodiversity of Kinorhyncha, including Echinoderes, the most speciose genus of the phylum. Among over 100 Echinoderes species described so far, which comprise about $40 \%$ of the total diversity within kinorhynchs, only eleven Echinoderes species are known from the Arctic region: E. angustus Higgins and Kristensen, 1988; E. aquilonius Higgins and Kristensen, 1988; E. arlis E. daenerysae Grzelak and Sørensen, 2017 in Grzelak and Sørensen 2018; E. drogoni Grzelak and Sørensen, 2017 in Grzelak and Sørensen 2018; 
E. eximus Higgins and Kristensen, 1988; E. peterseni Higgins and Kristensen, 1988; E. rhaegali Grzelak and Sørensen, 2017 in Grzelak and Sørensen 2018; E. stockmanni Adrianov, 1999 in Adrianov and Malakhov 1999; E. svetlanae Adrianov, 1999 in Adrianov and Malakhov 1999; and E. tubilak Higgins and Kristensen, 1988 (Higgins 1966a; Higgins and Kristensen 1988; Adrianov and Malakhov 1999; Grzelak and Sørensen 2018). The most extensive studies contributing to Arctic Echinoderes diversity and taxonomy were performed along the western coast of Greenland (Higgins and Kristensen 1988) and in the White Sea (Adrianov and Malakhov 1999). From the time of Adrianov's contributions and until 2017, no studies have dealt with the Arctic kinorhynch fauna. Only recently, Grzelak and Sørensen (2018) have investigated the occurrence of Echinoderes in Spitsbergen fjords, which has enabled the discovery of three new Arctic Echinoderes species and redescription of four out of five Echinoderes species already known from Greenland (Grzelak and Sørensen 2018). This demonstrates that the Svalbard archipelago and surrounding waters represent a region where high numbers of new kinorhynch species can be found and, thus, in respect to kinorhynch fauna it is a region particularly worthy of scientific attention.

In order to contribute to the knowledge about diversity and distribution patterns of Kinorhyncha, samples collected north off Svalbard and Spitsbergen surrounding waters have been investigated. Eleven stations spanning a wide range of environmental conditions were sampled: 100 to $2100-\mathrm{m}$ water depth, low to high chlorophyll $a$ content, variable sediment mean grain size. Most of the stations were located in the areas that have never been studied in respect of kinorhynchs diversity. In the present contribution, we list all Echinoderes species recorded so far in the Arctic region with information about their distribution, provide the description of new Arctic species, Echinoderes balerioni sp. nov., and redescribe E. arlis. This species was the first kinorhynch described from the Arctic region. Originally, it was found in the Chukchi Sea (Higgins 1966a), subsequently recorded northeast of Svalbard (Adrianov and Malakhov 1999) and recently in a fjord at Spitsbergen (Grzelak and Sørensen 2018). However, none of the reports contained SEM information about occurrence and appearance of taxonomically significant cuticular structures. Therefore, for the first time, morphological data revealed through SEM for E. arlis and new information about species diagnostics are provided.

\section{Materials and methods}

\section{Study site}

Sampling was undertaken in the European sector of the Arctic Ocean, at three sites located between $75-83^{\circ} \mathrm{N}$ and $5-21^{\circ} \mathrm{E}$ : (i) at the southwestern margin of Spitsbergen (station H6); (ii) on the shelf break and Arctic basin north off Svalbard archipelago (stations PS92/19-PS92/47); and (iii) at the southeastern part of Spitsbergen, in Storfjorden (station III) (Fig. 1). First site is located at the southwestern margin of Spitsbergen, close to the entrance to Hornsund fjord. This is an area under the influence of the northward flowing West Spitsbergen Current, which injects warm Atlantic Water into the Arctic Ocean, as well as cold Arctic waters transported by the Sørkaap Current. Remnants of pack ice from the Barents Sea are present in this area (Walczowski 2013). Second site covers the area from the shelf to the basins of the European Arctic margin and of the Yermak Plateau. This region is seasonally covered with sea ice, particularly with first- and second-year ice, and drift ice is present. Sea ice thickness and extension of the ice cover are related to the inflow of warm and saline Atlantic Water entering the Arctic Ocean through the eastern Fram Strait north of Spitsbergen. Third site, Storfjorden, is an inlet of the western Barents Sea, located between the main island of the Svalbard archipelago, Spitsbergen, in the west; Barentsøya and Edgøya in the east and limited by a shallow bank, Storfjordbanken, in the south. The fjord is app. $190 \mathrm{~km}$ long and rather shallow, with a maximum depth of $190 \mathrm{~m}$ (Fer et al. 2003). It is a region of coastal polynya activity during winter (Skogseth et al. 2004) and thus source of dense, brineenriched shelf water, which supplies the newly formed waters of the Arctic (Fer et al. 2003). Cold and fresh Arctic Water, originating as the East Spitsbergen Current, flowing through Storfjorden, passes the southern tip of Spitsbergen and travels northward along the west coast.

\section{Sample collection and preparation}

Material for the present contribution was collected during three cruises: (i) in August 2013 from board of the $R / V$ Oceania at station H6; (ii) in May and June 2015 from board of the R/V Polarstern in the deep-sea north of Svalbard (stations PS92/19-PS92/47); (iii) in May 2016 from board of the R/V Helmer Hanssen in Storfjorden (station III) (Table 1). At station H6, sediment samples were collected using a Niemistö gravity corer (9-cm inner diameter). Three cores, which were obtained from separate deployments, were sampled for meiofaunal analyses using a Plexiglas tube with an inner diameter of $3.6 \mathrm{~cm}$. At other stations, samples were collected using a giant box corer. Then, from each deployment, three sediment subsamples were collected using the same Plexiglas tube. The upper $5 \mathrm{~cm}$ of sediment were always taken and fixed in $4 \%$ formaldehyde solution in seawater buffered with borax. One additional sample from each station was collected to determine the grain size distribution. In the laboratory, analysis of grain size distribution was conducted using a set of sieves with 0.5 -phi intervals and/or a Counter Particle Size 
Fig. 1 Map showing locations of the sampling stations around Svalbard

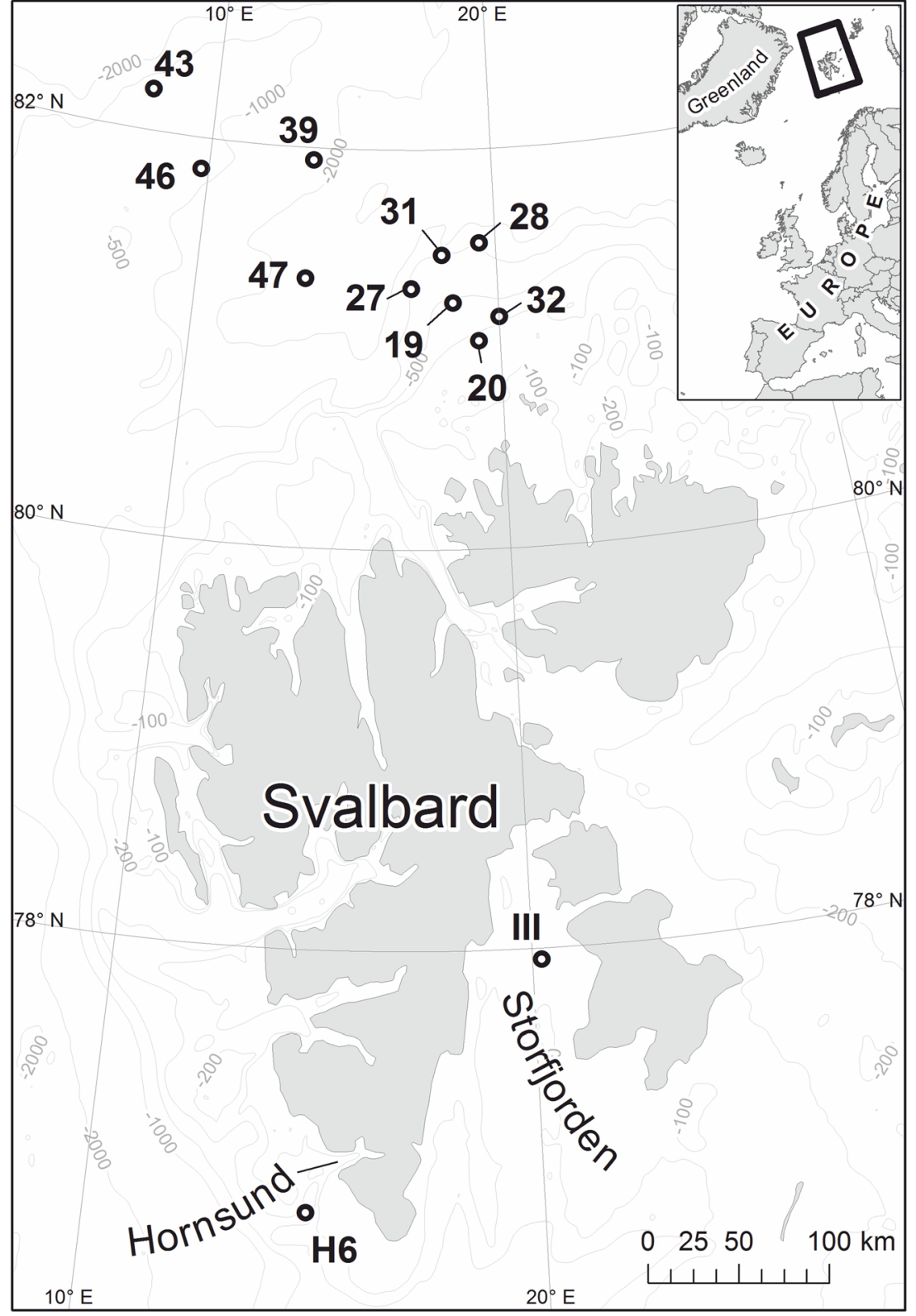

Analyzer. Mean grain size were calculated using Gradistat software (Blott and Pye 2001) and sediment characteristics were classified according to Folk and Ward (1957). Grain size data are presented in micrometers. Fixed biological samples were washed with freshwater in a $32-\mu \mathrm{m}$ sieve and meiofauna organisms were extracted using centrifugation method, with a solution of colloidal silica LUDOX TS50 (Vincx 1996). All meiofaunal organisms were counted and classified at higher taxonomic levels under a Nikon SMZ1500 stereomicroscope after staining with Bengal Rose to facilitate sorting process. After sorting, kinorhynchs were picked out and stored in a $4 \%$ formaldehyde solution. For preparation of light microscopy (LM) slides, specimens were dehydrated through a graded series of glycerin and mounted in Fluoromount-G. The specimens were examined using an Olympus BX51 (University of Copenhagen) and a Nikon E600 (Institute of Oceanology, Sopot), both equipped with differential interference contrast and drawing tubes. The microphotographic documentation was done using an Olympus DP27 camera. Measurements were made with $\mathrm{Cell}^{\wedge} \mathrm{D}$ software and are given in micrometers $(\mu \mathrm{m})$. All obtained dimensions reported in the tables are based on mounted LM specimens. Line art figures were made with Adobe Illustrator CS6. Specimens for scanning electron microscopy (SEM) were dehydrated through a graded alcoholacetone series and critical point dried. Dried specimens were mounted on aluminum stubs, sputter coated with 


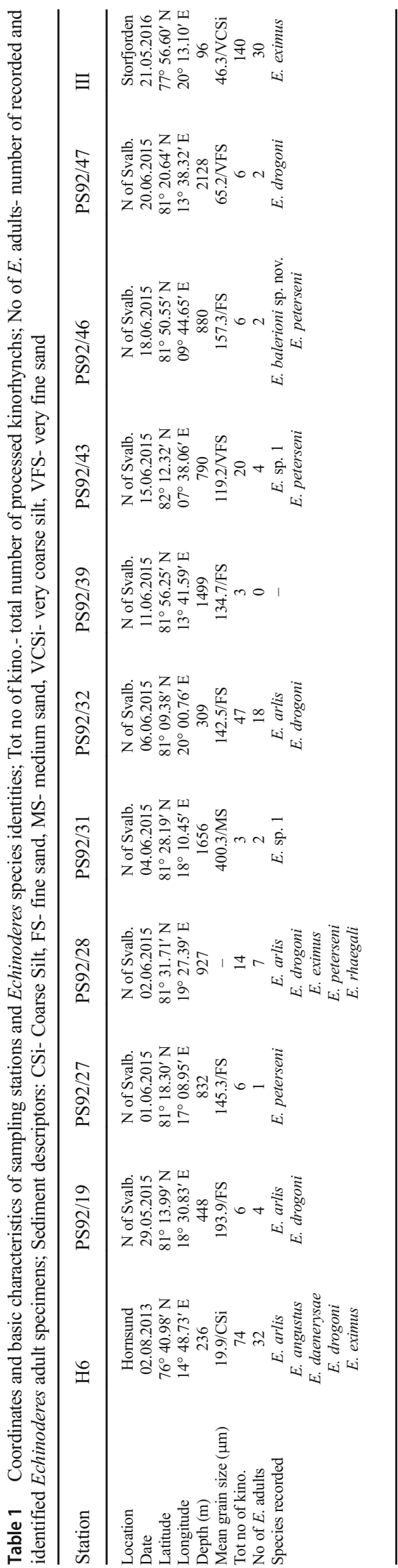

platinum-palladium mix, and examined with an FEI Inspect $\mathrm{S}$ scanning electron microscope.

\section{Results}

\section{Taxonomy}

Class Cyclorhagida (Zelinka, 1896) Sørensen et al., 2015

Order Echinorhagata Sørensen et al., 2015

Family Echinoderidae Zelinka, 1894

Genus Echinoderes Claparède, 1863

\section{Echinoderes balerioni sp. nov.}

This species is registered in ZooBank under urn:lsid:zoobank. org:pub:AEC03F05-E10F-4BAD-A4C4-9833BF089091

\section{Material examined}

Holotype Adult male, collected from mud on June 16, 2015, at station PS92/46 (Fig. 1, Table 1), at 880-m depth, north of Svalbard $\left(81^{\circ} 50.55^{\prime} \mathrm{N} 09^{\circ} 44.65^{\prime} \mathrm{E}\right)$, mounted in Fluoromount-G, deposited at the Natural History Museum of Denmark, under catalog number NHMD-202793.

\section{Etymology}

The species name refers to Balerion, one of the dragons commanded by Aegon I Targaryen, known from the books of George R.R. Martin.

\section{Diagnosis}

Species with short middorsal spines on segments 4,6 , and 8 , and spines in lateroventral positions on segments 6 to 9. Tubes present in laterodorsal, sublateral, and ventrolateral positions on segment 2, lateroventral positions on segment 5 , and lateral accessory positions on segment 8 . Tergal extensions conspicuously long and spiniform. Glandular cell outlets type 2 not present. Male with three pairs of penile spines.

\section{Description}

Holotypic male with head, neck, and 11 trunk segments (Figs. 2, 3). Overview of dimensions and measurements are given in Table 2. Distribution of cuticular structures is summarized in Table 3. Only a single specimen was available for LM examinations, and no specimens at all for SEM, thus some cuticular structures such as sensory spots or glandular cell outlets could not be identified. Therefore, structures are reported in Table 3 only when they were apparent in the 
Fig. 2 Line art illustrations of Echinoderes balerioni sp. nov. a male, dorsal view; b male ventral view. Abbreviations: gcol glandular cell outlet type 1, lat lateral accessory tube, $l d t$ laterodorsal tube, lts lateral terminal spine, lvs lateroventral spine, lvt lateroventral tube, $m d s$ middorsal spine, $m v p l$ midventral placid, $p c$ pachycyclus, pel-3 penile spines, $p f$ pectinate fringe, $s l t$ sublateral tube, $s p$ sternal plate, ss sensory spot, te tergal extension, $t p$ tergal plate, $\operatorname{tr} p$ trichoscalid plate, vlt ventrolateral tube

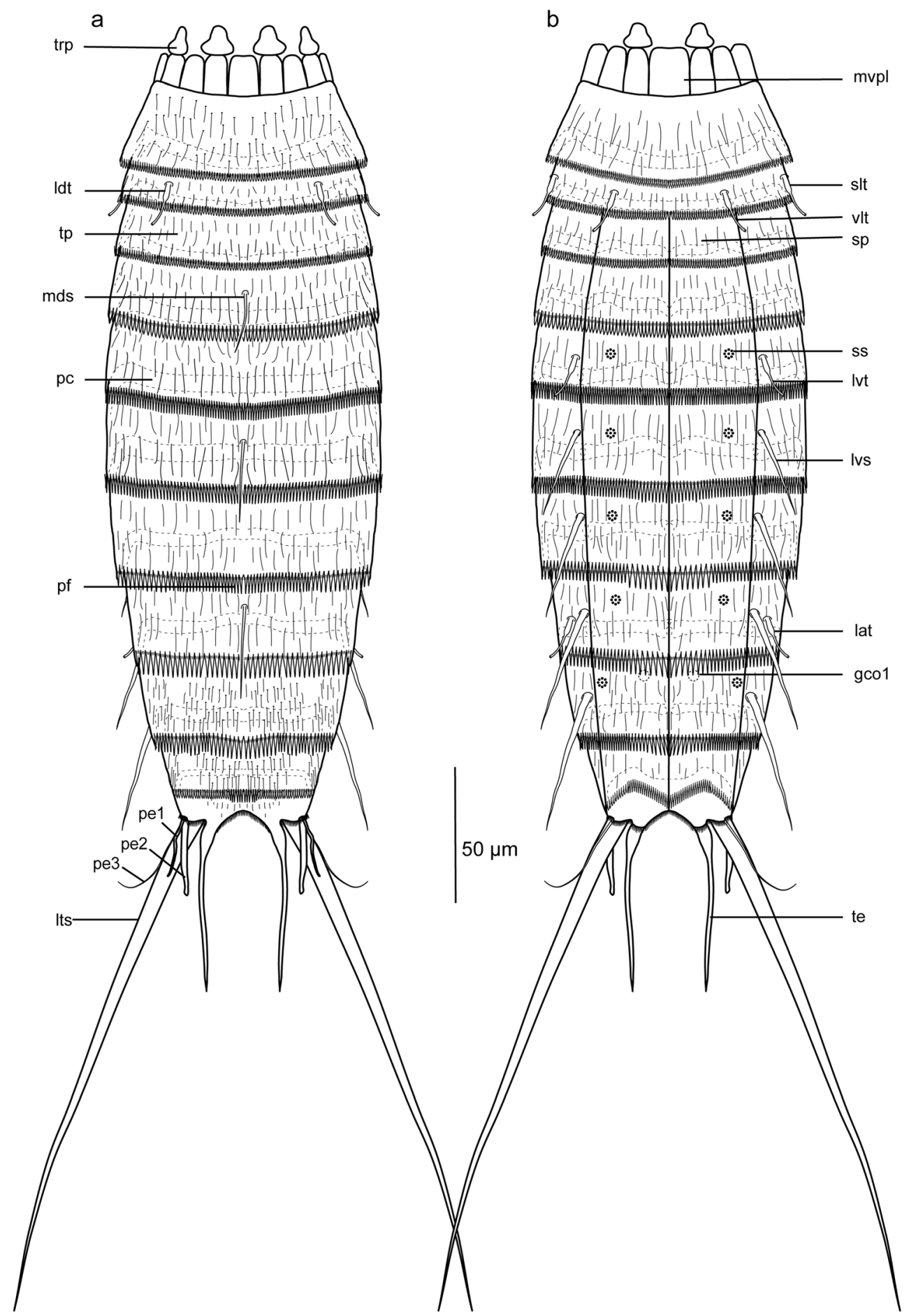

holotype. Lack of information regarding sensory spots and glandular cell outlets type 1 in the description of the segments should not necessarily be understood as a confirmation of their absence.

The neck has 16 placids, measuring $17.5 \mu \mathrm{m}$ in length. The midventral placid is broadest, measuring $14 \mu \mathrm{m}$ in width at its base, whereas all others are narrower measuring $10 \mu \mathrm{m}$ in width at their bases (Figs. 2b, 3c). Two dorsal and one ventral pair of trichoscalid plates, each with one attached trichoscalid, are present; ventral trichoscalid plates are slightly larger than the dorsal ones, but otherwise identical.

Segment 1 consists of a complete cuticular ring (Figs. 2, $3 a-c)$. Cuticular hairs abundant, distributed evenly around the segment, except at the anterior margin of the ventral side. Small, but easily visible rounded perforation sites present. Posterior segment margin almost straight, forming a pectinate 
Fig. 3 Light micrographs showing overview and details of Echinoderes balerioni sp. nov. male holotype (NHMD-202793). a Ventral overview. b Neck and segments 1-2, dorsal view. c Neck and segments 1-2, ventral view. d Segments 4-8, dorsal view. e Segment 2, ventral view. f Segments 5-7, ventral view. $\mathbf{g}$ Segments 10-11, ventral view. $\mathbf{h}$ Segments 8-11, dorsal view. i Segments 7-10, ventral view. $\mathbf{j}-\mathbf{I}$ Segments 10-11, focused through specimen from dorsal (j) to ventral (I). Abbreviations: lat lateral accessory tube, $l d t$ laterodorsal tube, lts lateral terminal spine, lvs lateroventral spine, $l v t$ lateroventral tube, $m d s$ middorsal spine, $p c$ pachycyclus, pel-3 penile spines, $p f$ pectinate fringe, slt sublateral tube, $s p$ sternal plate, te tergal extension, $t p$ tergal plate, $v l t$ ventrolateral tube, vmgcol ventromedial glandular cell outlet type 1, vmss ventromedial sensory spots
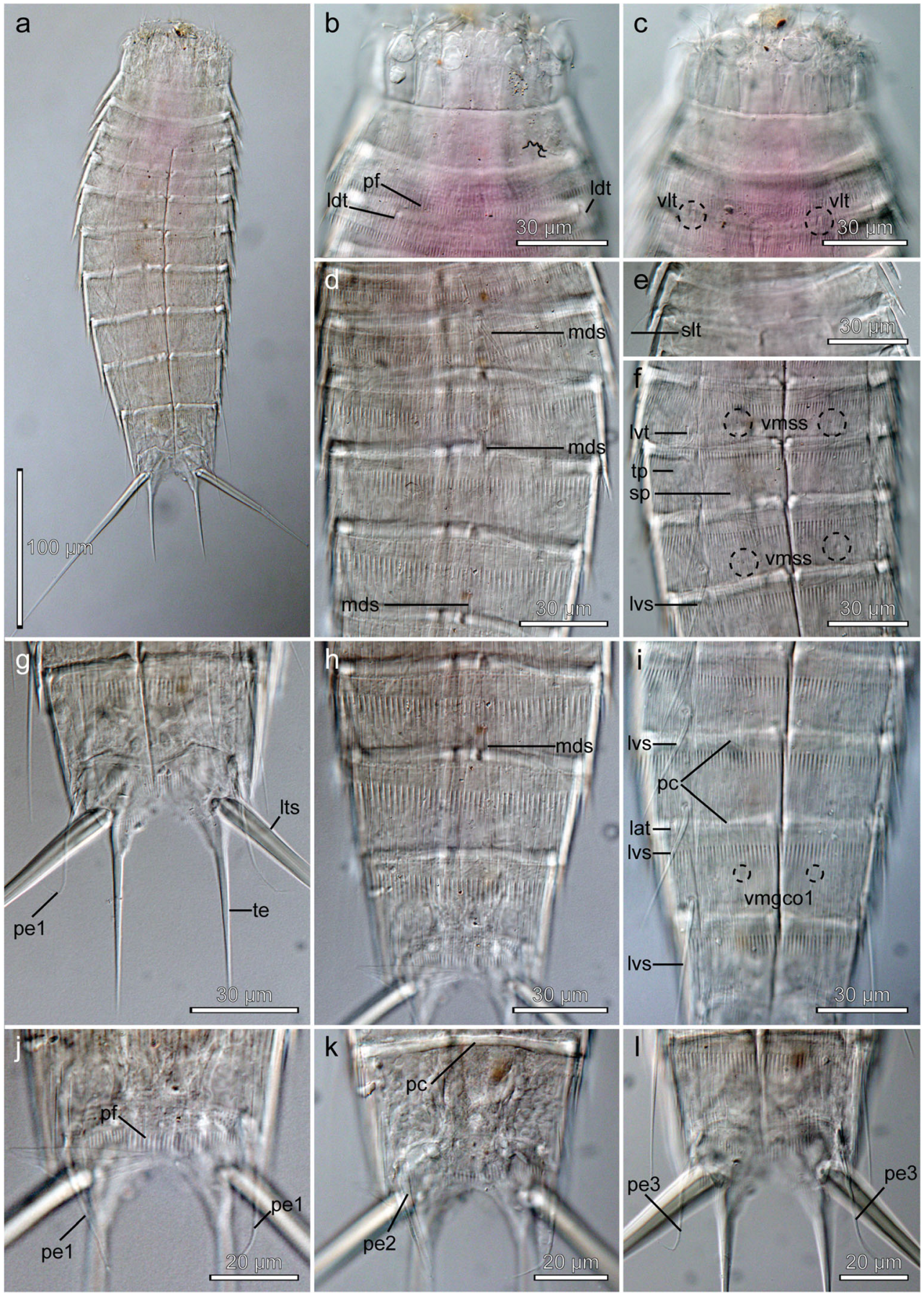

fringe. Fringe with well-developed short tips, homogenous along the segment margin.

Segment 2 consists of a complete cuticular ring, with tubes located in laterodorsal, sublateral, and ventrolateral positions (Figs. 2, 3b-c, e). Cuticular hairs slightly shorter than those of preceding segment, but pectinate fringe as on segment 1 .

Segment 3, and all following segments, consists of one tergal and two sternal plates (Figs. 2, 3a, f). Pachycyclus of the anterior segment margin of regular thickness, with middorsal interruption, at this and following six segments and with interruptions around tergosternal and midsternal junctions, at this and following seven segments. Cuticular hairs and pectinate fringe as on preceding segments. Pectinate fringe of segments 1-3 shorter than on following segments.

Segment 4 with short middorsal acicular spine (Figs. 2a, 3d). Cuticular hairs as on segment 3. Pectinate fringe of this segment with considerable longer fringe tips than on preceding segments.

Segment 5 with lateroventral tubes and ventromedial sensory spots (Figs. 2b, 3f). Cuticular hairs as on preceding 
Table 2 Measurements from light microscopy of Echinoderes balerioni sp. nov., male holotype (in $\mu \mathrm{m}$ ) from north of Svalbard, station PS92/46

\begin{tabular}{lc}
\hline Character & Length \\
\hline TL & 300 \\
MSW-6 & 64 \\
MSW-6/TL & $21.3 \%$ \\
SW-10 & 52 \\
SW-10/TL & $17.3 \%$ \\
S1 & 32 \\
S2 & 30 \\
S3 & 31 \\
S4 & 36 \\
S5 & 39 \\
S6 & 45 \\
S7 & 46 \\
S8 & 48 \\
S9 & 47 \\
S10 & 43 \\
S11 & 73 \\
MD4 (ac) & 23 \\
MD6 (ac) & 32 \\
MD8 (ac) & 35 \\
LA5 (tu) & 15 \\
LV6 (ac) & 34 \\
LV7 (ac) & 40 \\
LA8 (ac) & 47 \\
LV9 (ac) & 52 \\
LTS & 181 \\
LTS/TL & \\
\hline
\end{tabular}

ac acicular spin; $L A$ lateral accessory; LTS lateral terminal spine; $L V$ lateroventral; $M D$ middorsal; $M S W-6$ maximum sternal width, measured on segment 6 in this species; $S$ segment lengths; $S W$ - 10 standard width, always measured on segment 10 ; $T L$ trunk length; $t u$ tube

segment. Pectinate fringe on posterior segment margin with slightly longer and narrower fringe tips than on preceding segment.

Segment 6 with acicular spines in middorsal and lateroventral positions (Figs. 2, 3d, f). Sensory spots present at least in ventromedial positions. Cuticular hairs on tergal and sternal plates similarly distributed as on preceding segment, except for narrow hairless line in laterodorsal and paraventral areas. Segment otherwise as preceding segment.

Segment 7 with acicular spines in lateroventral positions and sensory spots in ventromedial positions (Fig. 2b). Cuticular hairs on tergal plate less dense than on preceding segment. Pectinate fringe with longer and wider fringe tips along the paraventral area of the segment margin than on previous segment.

Segment 8 with acicular spines in middorsal and lateroventral positions and tubes located in lateral accessory positions (Figs. 2b, 3h-i). At least one pair of sensory spots in ventromedial position. Segment otherwise as preceding segment.

Segment 9 with acicular spines in lateroventral positions (Figs. 2b, 3i). Sensory spots present in ventrolateral positions, glandular cell outlets type 1 located ventromedially (Figs. 2b,
Table 3 Summary of nature and location of sensory spots, glandular cell outlets, tubes, and spines arranged by series in Echinoderes balerioni sp. nov.

\begin{tabular}{lllllllll}
\hline Position segment & MD & LD & ML & SL & LA & LV & VL & VM \\
\hline 1 & & & & & & & & \\
2 & & tu & & tu & & & tu & \\
3 & & & & & & & & \\
4 & ac & & & & & & & \\
5 & & & & & & tu & & ss \\
6 & ac & & & & ac & ss \\
7 & & & & & & ac & & ss \\
8 & ac & & & tu & ac & & ss \\
9 & & & & & & ac & ss & gco 1 \\
10 & & & & & & & & \\
11 & & pe & & lts & & \\
\hline
\end{tabular}

$L A$ lateral accessory, $L D$ Laterodorsal, $L V$ lateroventral, $M D$ middorsal, $M L$ midlateral, $S L$ sublateral, $V L$ ventrolateral, $V M$ ventromedial, $a c$ acicular spine, gco 1 glandular cell outlet type 1, lts lateral terminal spine, pe penile spine, $s s$ sensory spot, $t u$ tube

3i). Sieve plate not visible in LM. Cuticular hairs on the tergal plate slightly shorter than on preceding segment. Segment otherwise as preceding segment.

Segment 10 with fewer cuticular hairs both on the dorsal and ventral sides. Pachycyclus of the anterior segment margin without middorsal interruption (Fig. 3k). Pectinate fringe of this segment conspicuously shorter than on preceding segment. The posterior edge of the sternal plates extends in the ventromedial and paraventral positions, forming a V-shape. The pectinate fringe is also slightly longer in these areas; fringe tips along the posterior margin of tergal plate short and narrow, with exception of paradorsal area with longer fringe tips (Fig. 3j).

Segment 11 with lateral terminal spines (Figs. 2, 3a, j-1). Three pairs of penile spines present in male holotype. First and third pair long, thin, and flexible (Figs. 3j, 1), while second pair is markedly stouter, more rod-like, but still relatively long (Fig. 3k). Tergal extensions conspicuously long and spiniform (Figs. 2, 3a, g). Sternal plates with rounded posterior margins, with minute pectinate fringe. Cuticular hairs not visible on this segment.

\section{Differential diagnosis}

Echinoderes balerioni sp. nov. cannot be confused with any other species by its combination of spines and tubes formula and conspicuously long tergal extension. The most prominent feature in E. balerioni sp. nov. is tergal extension that constitutes almost $18.3 \%$ of the total trunk length. This value markedly exceeds other TE/TL ratios in species with elongated terminal tergal extensions, including E. spinifurca Sørensen et al. 2005; E. higginsi Huys \& Coomans, 1989; or E. arlis, 
which TE/TL ratios vary between $5.3 \%$ in E. arlis (present study) and $10.6 \%$ in E. spinifurca (Huys and Coomans 1989; Sørensen et al. 2005). Length of tergal extension in $E$. balerioni sp. nov. is comparable only with the tergal extensions of E. cernunnos Sørensen et al. 2012, which is the species with the longest tergal extension known so far. Interestingly, in both species, TE/TL ratio exceeds $18 \%$, while the proportion between tergal extensions and total segment length is about $70 \%$ (Sørensen et al. 2012). However, this species is easily distinguished from E. balerioni sp. nov. by its five middorsal spines on segments 4 to 8 , presence of glandular cell outlets type 2 on segments 2, 5, 7, and 8, and middorsal fissure on segment 11. Among the abovementioned species, also $E$. spinifurca is characterized by five middorsal spines, which makes it impossible to confuse the species with E. balerioni sp. nov. Only two other congeners, E. higginsi and $E$. arlis (the latter being redescribed in the present contribution), have elongated and pointed tergal extensions, and three middorsal spines attached to segments 4, 6, and 8 . Nevertheless, both species can easily be discriminated from E. balerioni sp. nov. by the tube formula on segment 2 with only one pair present in ventrolateral positions, presence of glandular cell outlets type 2 on segment 2 (E. arlis), and longer middorsal spines.

Echinoderes species that show the closest resemblance in spine and tube formulas with E. balerioni sp. nov. are E. hispanicus Pardos et al., 1998; E. newcaledoniensis Higgins, 1967; and E. peterseni (Higgins 1967; Higgins and Kristensen 1988; Pardos et al. 1998; Grzelak and Sørensen 2018). All share with E. balerioni presence of middorsal spines on segments 4,6 , and 8 , lateroventral spines/tubes on segments 5 to 9 , three pairs of tubes on segment 2, and presence of lateral accessory tubes on segment 8. Furthermore, similar to E. balerioni sp. nov., all show absence of glandular cell outlets type 2 (Pardos et al. 1998; Sørensen et al. 2016; Grzelak and Sørensen 2018). However, except for the obviously shorter and differently shaped tergal extensions, abovementioned species can be distinguished from E. balerioni sp. nov. by other characters, such as the presence of an additional pair of tubes in midlateral position on segment 8 (E. hispanicus) or pair of lateral accessory tubes on segment 9 (E. newcaledoniensis). The only species which shares almost identical spine and tube pattern with E. balerioni sp. nov. is $E$. peterseni. The subtle difference is presence of tubes on segment 2 in subdorsal rather than laterodorsal positions, as in E. balerioni sp. nov. and laterodorsal tubes on segment 10. The latter trait even has to be used with caution since tubes on the dorsal side of segment 10 might be difficult to visualize with LM. Nevertheless, E. peterseni can be still easily distinguished from E. balerioni sp. nov. based on overall body appearance with conspicuously shorter and differently shaped tergal extension as a key character, together with different middorsal and lateroventral spine dimensions. Acicular spines in middorsal positions in E. balerioni sp. nov. are almost half as long as the ones in E. peterseni, while lateroventral spines in E. balerioni sp. nov. are on average $41-79 \%$ longer than in E. peterseni.

\section{Echinoderes arlis Higgins, 1966}

\section{Material examined}

LM examination: male allotype (USMN 32923) and two female paratypes (USMN 1209775, USMN 1209777) of E. arlis collected below 400-m depth in the Chukchi Sea, loaned from the Smithsonian Institution, United States National Museum. Additional material includes 10 specimens collected in 2016 from stations PS92/19, PS92/28, and PS92/32 located north of Svalbard (Fig. 1, Table 1), stored in the Natural History Museum of Denmark (NHMD202803 to NHMD-202812) and 13 specimens collected in 2013 from station H6 located at the entrance of Hornsund fjord, stored in the Natural History Museum of Denmark (NHMD-228965 to NHMD-228977).

SEM examination: 10 specimens of $E$. arlis from stations H6 and PS92/32, stored in the personal collection of MVS.

\section{Emended diagnosis}

Species with middorsal spines on segments 4,6 , and 8 , and spines in lateroventral positions on segments 6 to 9. Tubes present in ventrolateral positions on segment 2 , sublateral positions on segment 5 , and laterodorsal tubes on segment 10 ; tubes in sublateral positions on segment 8 show intraspecific variation, and may or may not be present. Glandular cell outlets type 2 present in subdorsal and sublateral positions on segment 2.

\section{Description}

Adults with head, neck, and 11 trunk segments (Figs. 4, 5, 6). Overview of measures and dimensions are given in Table 4. Distribution of cuticular structures, i.e., sensory spots, glandular cell outlets, spines, and tubes, is summarized in Table 5.

All specimens mounted for SEM had their introverts either fully or partially retracted; hence, it was not possible to provide any details regarding scalids arrangement and morphology.

Neck with 16 placids, measuring $16 \mu \mathrm{m}$ in length. The midventral placid is broadest, measuring $14 \mu \mathrm{m}$ in width at its base. Remaining placids narrower; measuring $10 \mu \mathrm{m}$ in width at their bases at the ventral side and slightly narrower, measuring $8.5 \mu \mathrm{m}$ at their bases at the dorsal side. The trichoscalid plates are well-developed, equal in length, each with one attached trichoscalid.

Segment 1 consists of a complete cuticular ring (Figs. $4 \mathrm{a}-$ b, $5 \mathrm{a}-\mathrm{d}, 6 \mathrm{~b}-\mathrm{d})$. Four pairs of sensory spots are located in subdorsal, laterodorsal, midlateral, and ventromedial 
Fig. 4 Line art illustrations of Echinoderes arlis. a Male, dorsal view. b Male, ventral view. c Female, segments 10-11, dorsal view. d Female, segments 10-11, ventral view. Abbreviations: gcol glandular cell outlet type 1, gco 2 glandular cell outlet type 2 , ldt laterodorsal tube, ltas lateral terminal accessory spine, lts lateral terminal spine, $l v s$ lateroventral spine, $m d s$ middorsal spine, $m v p l$ midventral placid, $p c$ pachycyclus, $p e 1-3$ penile spines, $p f$ pectinate fringe, si sieve plate, slt sublateral tube, $s p$ sternal plate, $s s$ sensory spot, $t p$ tergal plate, $v l t$ ventrolateral tube; * character might be missing in some specimens

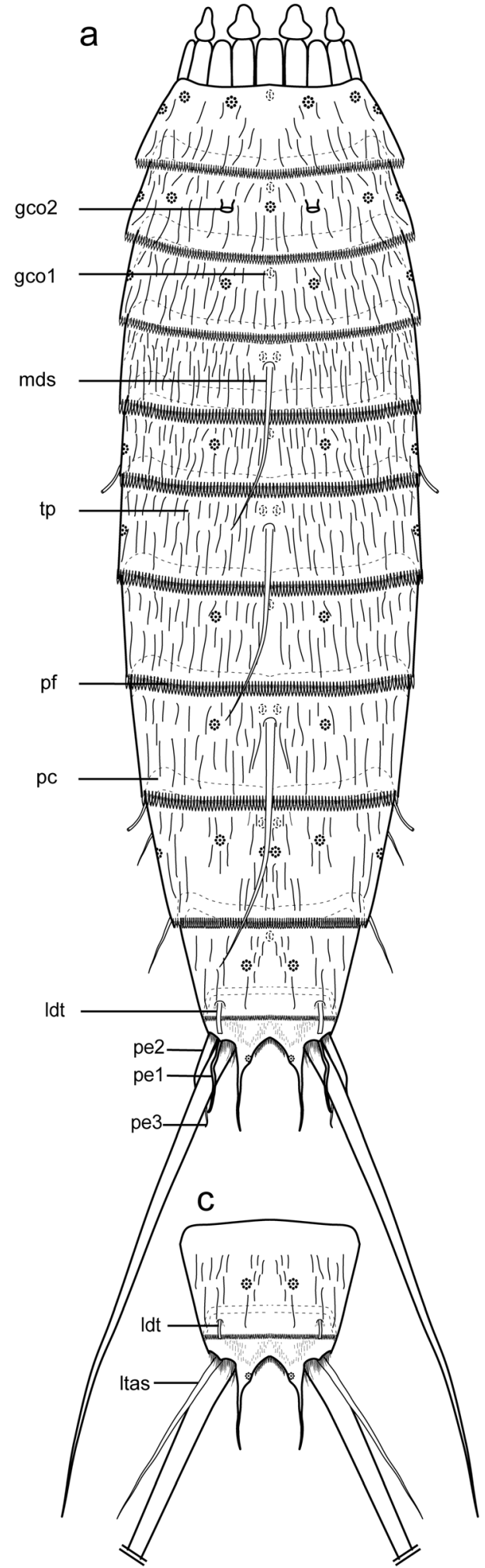

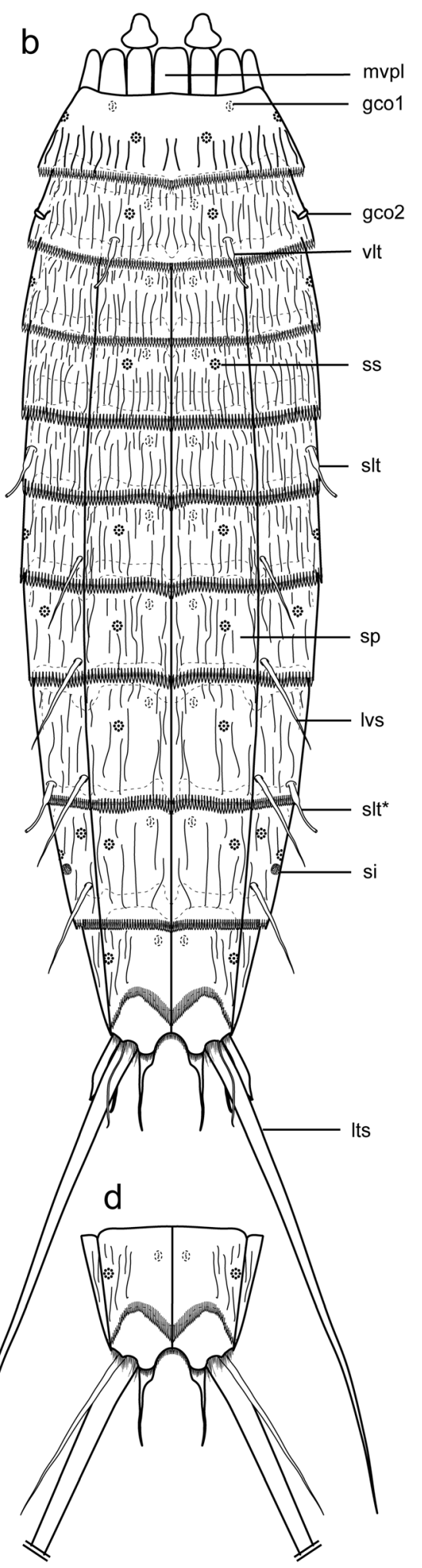

positions. Dorsal sensory spots are located anterior on the segment, very close to the segment margin, and medially in ventromedial positions (Fig. 6c-d). Sensory spots on this and following five segments are rather small and rounded, with numerous short micropapillae surrounding a central pore and one longer hair coming out from the pore center. Glandular cell outlet type 1 present in middorsal and ventrolateral positions, near anterior margin of segment. Cuticular hairs lightly scattered on the dorsal side, while on lateral and ventral sides distributed more densely, forming a line on the 
Fig. 5 Light micrographs showing overviews and details of Echinoderes arlis male collected at station 32, north off Svalbard. a Dorsal overview. b Ventral overview. c Neck and segments 1-5, dorsal view. d Neck and segments $1-5$, ventral view. e Segments 5-7, ventral view. f Segments 8-9 with sublateral tube on segment 8 , ventral view. $\mathbf{g}$ Segments 10-11, ventral view. h Segments 8-9 without sublateral tube on segment 8 (arrow), ventral view. Abbreviations: lts lateral terminal spine, $l v s$ lateroventral spine, $\mathrm{mdgcol}$ middorsal glandular cell outlet type $1, m d s$ middorsal spine, pdgcol paradorsal glandular cell outlet type 1, pe penile spine, sdgco 2 subdorsal glandular cell outlet type 2, sdss subdorsal sensory spots, $s i$ sieve plate, slgco2 sublateral glandular cell outlet type 2, slt sublateral tube, te tergal extension, vlt ventrolateral tube, vmgcol ventromedial glandular cell outlet type 2, vmss ventromedial sensory spot
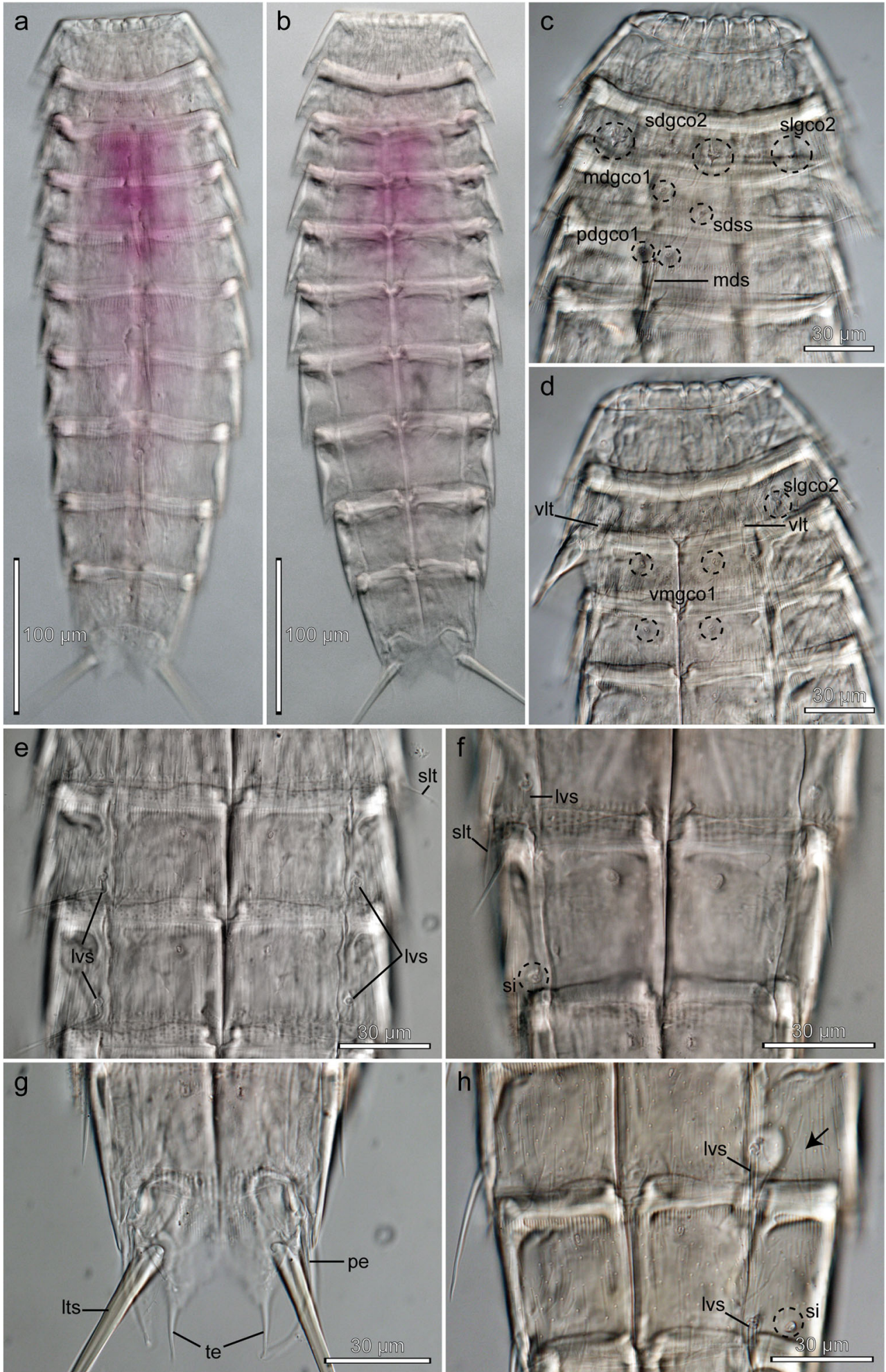

posterior segment margin, close to the pectinate fringe (Fig. 6b-d). The posterior segment margin is straight, forming a pectinate fringe. Fringe tips well-developed, homogenous along segment margin.
Segment 2 consists of a complete cuticular ring, with tubes located in ventrolateral positions. Two pairs of large, rounded glandular cell openings type 2 are located in subdorsal and sublateral positions (Figs. $4 \mathrm{a}-\mathrm{b}, 5 \mathrm{c}-\mathrm{d}, 6 \mathrm{c}-\mathrm{d}$ ). Sensory spots 
present in middorsal, laterodorsal, midlateral, and ventromedial positions. Glandular cell outlets type 1 present in middorsal and ventromedial positions. Cuticular hairs slightly more densely distributed on the ventral than on the dorsal side. Pectinate fringe of posterior margin as on preceding segment.

Segment 3, and remaining segments, consisting of one tergal and two sternal plates. Segment with sensory spots in subdorsal and midlateral positions, and glandular cell outlets type 1 in middorsal and ventromedial positions. Pachycyclus of the anterior segment margin of regular thickness, without middorsal interruption, at this and following segments. Cuticular hairs and pectinate fringe as on preceding segment.

Segment 4 with flexible acicular spine in middorsal position (Figs. 4a, 5a, c, 6c). Segment with sensory spots in ventromedial positions only, and with glandular cell outlets type 1 in paradorsal and ventromedial positions. Cuticular hairs relatively dense and evenly distributed over tergal plate, but with interruption in the middorsal and midlateral areas; hairs on the sternal plates as on preceding segment. Fringe tips of pectinate fringe on posterior segment margin slightly longer than on preceding segment.

Segment 5 with tubes in sublateral positions (Figs. 4b, 5e, $6 e$ ) and pairs of sensory spots in subdorsal and midlateral positions. Glandular cell outlets type 1, present in middorsal and ventromedial positions. Pectinate fringe of posterior margin and cuticular hairs otherwise as on preceding segments.

Segment 6 with acicular spines in middorsal and lateroventral positions (Figs. 4, 5e, 6e), and with sensory spots present in midlateral and ventromedial positions. Two pairs of glandular cell outlets type 1 located paradorsally and ventromedially. Cuticular hairs on tergal plate similarly distributed as on preceding segment; hairs on the sternal plates interrupted by small hairless ventromedial patch. Pectinate fringe of posterior margin at this and following two segments as on preceding one.

Segment 7 with acicular spines in lateroventral positions (Figs. 4b, 5e, 6e), sensory spots in subdorsal, sublateral, and ventromedial positions, and glandular cell outlets type 1 in middorsal and ventromedial positions (Fig. 4). Cuticular hairs otherwise as on preceding segments.

Segment 8 with acicular spines in middorsal and lateroventral positions and tubes in sublateral positions (Figs. 4, 5f, h, 6f-g). Eighteen specimens (out of 33 examined under both LM and SEM) lacked sublateral tubes, while such tubes were present in 13 specimens; for two specimens presence/absence could not be confirmed. Tubes observed neither for male allotype nor for female paratype specimens. The absence of tubes appeared independent of gender. Segment with sensory spots in subdorsal and ventromedial positions and two pairs of glandular cell outlets type 1 located paradorsally and ventromedially. Cuticular hairs on tergal plate distributed as on preceding segment; hairs on the sternal plates slightly less dense than on preceding segment.
Segment 9 with acicular spines in lateroventral positions. Five pairs of sensory spots present in paradorsal, subdorsal, midlateral, and ventrolateral positions (Figs. $4 \mathrm{a}-\mathrm{b}, 5 \mathrm{~g}$ ). Glandular cell outlets type 1 present as on preceding segment, in paradorsal and ventromedial positions. A pair of small, round sieve plates present in sublateral position (Figs. 4b, 5f, $6 \mathrm{~g})$. Cuticular hair covering on tergal plate scarcer than on preceding segment, with some hairless patches present in subdorsal and laterodorsal areas; sternal plate hair covering as on preceding segment. Pectinate fringe tips slightly shorter on lateral sides, otherwise as on preceding segments.

Segment 10 with laterodorsal tubes at the posterior segment margin; tubes stronger and longer $(13 \mu \mathrm{m})$ in males than in females $(4.5-5 \mu \mathrm{m})$ (Figs. $4 \mathrm{a}, \mathrm{c}, 6 \mathrm{~h}-\mathrm{i})$. Sensory spots present in subdorsal and ventrolateral positions. Glandular cell outlets type 1 located middorsally and paraventrally. Segment with fewer cuticular hairs over tergal plate than on preceding segment; sternal plates in paraventral and ventromedial areas devoid of hairs. Pectinate fringe of posterior margin of tergal plate with short and narrow fringe tips, whereas longer fringe tips forming a V-shape are present in ventromedial and paraventral areas of sternal plates (Figs. $4 \mathrm{a}-$ b, 6h).

Segment 11 with lateral terminal spines (Figs. 4, 5g, 6h-i). Females with lateral terminal accessory spines (Figs. 4c-d, 6h) and males with three pairs of penile spines (Figs. 4a-b, $5 \mathrm{~g}, 6 \mathrm{i})$. Dorsal and ventral pairs of penile spines are long and flexible, whereas medial pair is shorter, stouter, and coneshaped (Figs. 4a, b, 5g, 6i). Small sensory spots present in subdorsal position, at the margin of tergal extension (Fig. 6h). Glandular cell outlets type 1 absent. The segment is devoid of cuticular hairs in both sexes, but with short cuticular hair-like structures covering area on the dorsal side (Fig. 6h). Tergal extensions are markedly elongated and pointed (Fig. 6h-i). Sternal extensions are rounded, not extending beyond the tergal extensions. Pectinate fringe of posterior segment margin with long, narrow, and flexible fringe tips, particularly in laterodorsal, lateroventral, and ventrolateral positions.

\section{Differential diagnosis}

Echinoderes arlis is one of 22 species (inclusive E. balerioni sp. nov.) having middorsal spines on segments 4, 6 and 8, but can be easily distinguished from all other congeners by its unique pattern of spines and tubes. The most exclusive feature of $E$. arlis is presence of tubes on segment 5 in sublateral positions. Displacement of lateroventral tubes on segment 5 is very rare and only known for $E$. drogoni. However, its tubes are present in lateral accessory positions, and it has middorsal spines on segments 4 to 8 (Grzelak and Sørensen 2018). Presence of sublateral tubes on segment 8 is also rather unusual. Only six other species, i.e., E. astridae Sørensen, 2014; 

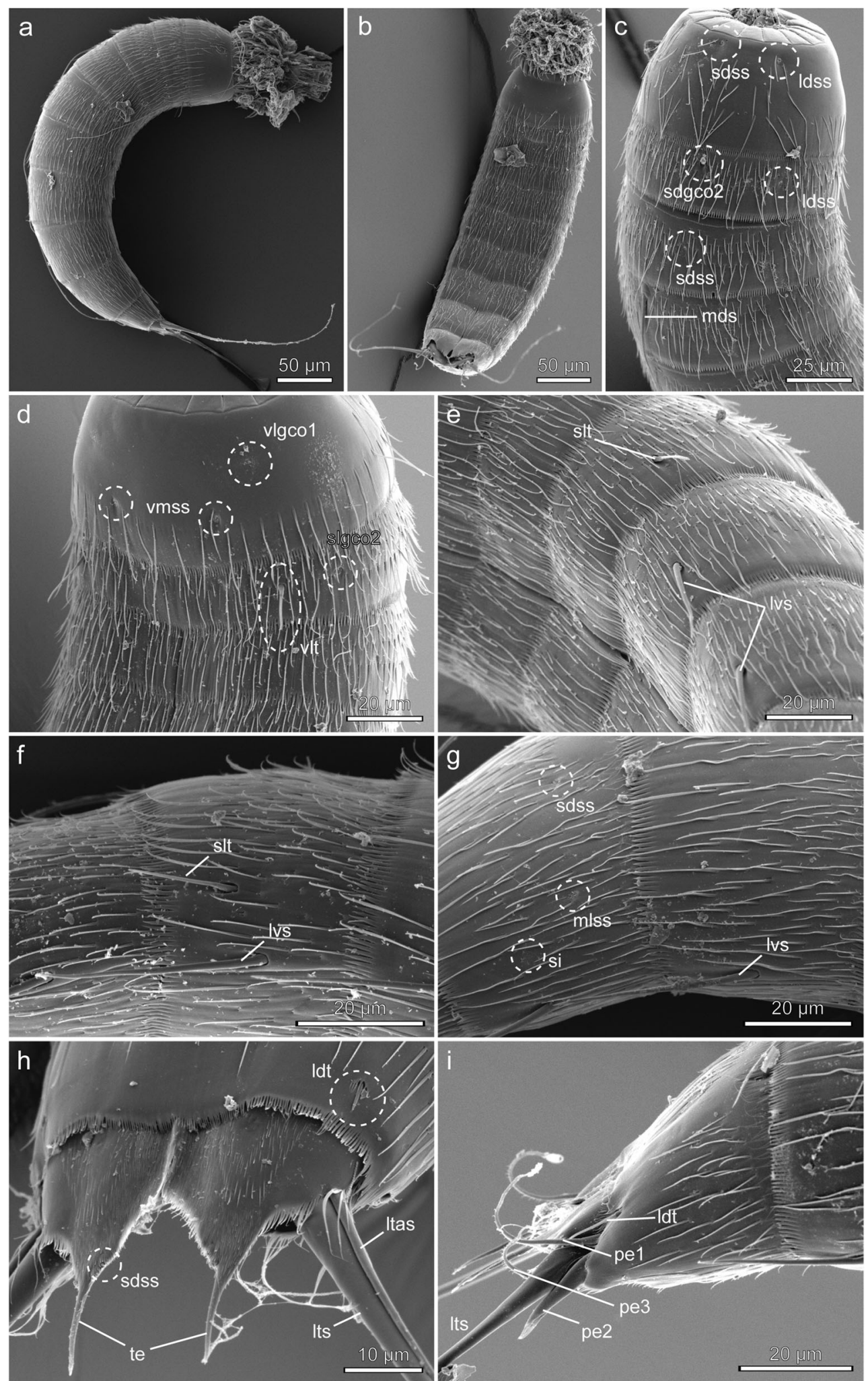

E. augustae Sørensen \& Landers, 2014; E. levanderi Karling, 1954; E. regina Yamasaki, 2016; E. reicherti Neves et al. 2016; and E. serralatus Yamasaki, 2016 possess tubes on segment 8 in this position, but none of them have three middorsal spines as E. arlis (Sørensen 2014, unpublished obs. for E. levanderi; Sørensen and Landers 2014; Neves et al. 2016; 
Fig. 6 Scanning electron micrographs showing overview and details in trunk morphology of Echinoderes arlis collected north off Svalbard. a Lateral overview of female specimen. b Ventral overview of male specimen. c Neck region and segments 1-4, laterodorsal view. d Segments 1-3, ventrolateral view. e Segments 4-7, lateroventral view. f Segments 8-9 with sublateral tube on segment 8, lateral view. $g$ Segments 8-9 without sublateral tube on segment 8, lateral view. h Segments 10-11 of female, dorsal view. i Segments $10-11$ of male, lateral view. Abbreviations: ldss laterodorsal sensory spot, $l d t$ laterodorsal tube, ltas lateral terminal accessory spine, lts lateral terminal spine, $l v s$ lateroventral spine, $m d s$ middorsal spine, mlss midlateral sensory spot, pe penile spines, sdgco 2 subdorsal glandular cell outlet type 2, sdss subdorsal sensory spot, $s i$ sieve plate, slgco 2 sublateral glandular cell outlet type 2 , slt sublateral tube, te tergal extensions, $v$ lgcol ventrolateral glandular cell outlet type 1, vlt ventrolateral tube, vmss ventromedial sensory spot

Yamasaki 2016b). However, since sublateral tubes on segment 8 might be missing for some specimens of $E$. arlis, this character should be treated with caution. Nevertheless, apart from sublateral tubes on segment 5 and 8 , arrangement of other tubes and glandular cell outlets type 2 makes $E$. arlis markedly different from most congeners. Presence of only one pair of tubes on segment 2 in lateroventral/ventrolateral positions is shared with 10 other species having middorsal spines on segment 4, 6, and 8, among which 5 (E. higginsi, E. kristenseni Higgins, 1985, E. riceae Herranz et al. 2014, E. riedli Higgins, 1966, E. wallaceae Higgins, 1983) are characterized by having lateral accessory tubes on segment 8 (Higgins 1966b, 1983, 1985; Huys and Coomans 1989; Herranz et al. 2014), whereas only 2 species (E. kristenseni and $E$. wallaceae) also show presence of two pairs of glandular cell outlets type 2 on segment 2 (Sørensen et al. 2016). Echinoderes riceae can easily be discriminated from $E$. arlis by its spine formula lacking the lateroventral spine on segment 6, and E. riedli and E. higginsi show considerably smaller trunk and spines dimensions (although the latter species has long terminal tergal extension, somehow similar to those of E. arlis). Among the abovementioned species, E. kristenseni and $E$. wallaceae appeared most similar to $E$. arlis. Both species share with $E$. arlis the same spines pattern on the dorsal and ventral side, the presence of paired tubes located on the lateroventral/ventrolateral side of segment 2 , and two pairs of glandular cell outlets type 2 on segment 2. Echinoderes kristenseni, similar to E. arlis, possesses laterodorsal tubes on segment 10 (Higgins 1985). However, both E. kristenseni and $E$. wallaceae have a second pair of glandular cell outlets type 2 located in lateroventral position on segment 2 , while in E. arlis this pair is located sublaterally. Besides this, except for remarkable differences in location of tubes on segments 5 and 8 , i.e., lateroventral tubes on segment 5 and lateral accessory tubes on segment 8 in both species, E. kristenseni and E. wallaceae differ in the shape of the tergal extension and body size. As mentioned above, the tergal extensions of E. arlis are conspicuously long and pointy, while trunk length is significantly higher (av. length $423 \mu \mathrm{m}$ ) than in
E. wallaceae (av. length $236 \mu \mathrm{m}$ ) and in E. kristenseni (max length $285 \mu \mathrm{m}$ ). Moreover, unique spine and tube patterns, together with presence of glandular cell outlets type 2, mean that E. arlis is also easily distinguished from other Arctic Echinoderes species. Three other species, E. peterseni, E. rhaegali and, described in this paper, E. balerioni $\mathrm{sp}$. nov., possess the same spine pattern on its dorsal side, with middorsal spines on segments 4,6 , and 8 . However, all three share distinctive characters: lack of glandular cell outlets type 2, presence of two (E. rhaegali) or three (E. peterseni, $E$. balerioni sp. nov.) pairs of tubes on segment 2, lateroventral/lateral accessory tubes on segment 5 , and lateral accessory tubes on segment 8 . All three species are also considerably shorter than $E$. arlis.

Table 4 Measurements from light microscopy of Echinoderes arlis (in $\mu \mathrm{m})$ from north of Svalbard, station PS92/32, including number of measured specimens $(n)$ and standard deviation (SD)

\begin{tabular}{|c|c|c|c|c|}
\hline Character & $n$ & Range & Mean & $\mathrm{SD}$ \\
\hline TL & 10 & $389-452$ & 423 & 21.01 \\
\hline MSW-6 & 10 & $69-85$ & 78 & 4.85 \\
\hline MSW-6/TL & 10 & $17.1-19.2 \%$ & 18.4 & 0.67 \\
\hline SW-10 & 10 & $52-70$ & 62 & 5.54 \\
\hline SW-10/TL & 10 & $13.4-16.7 \%$ & 14.8 & 1.20 \\
\hline S1 & 10 & $43-50$ & 47 & 2.58 \\
\hline S2 & 10 & $37-45$ & 42 & 2.50 \\
\hline S3 & 10 & $39-47$ & 44 & 2.53 \\
\hline S4 & 10 & $39-49$ & 45 & 3.37 \\
\hline S5 & 10 & $40-54$ & 48 & 4.47 \\
\hline S6 & 10 & $48-57$ & 53 & 3.06 \\
\hline S7 & 10 & $47-65$ & 57 & 5.73 \\
\hline S8 & 10 & $52-68$ & 61 & 4.65 \\
\hline S9 & 10 & $60-69$ & 64 & 2.77 \\
\hline $\mathrm{S} 10$ & 10 & $48-59$ & 55 & 3.89 \\
\hline S11 & 10 & $49-54$ & 52 & 2.13 \\
\hline MD4 (ac) & 9 & $70-84$ & 78 & 4.01 \\
\hline MD6 (ac) & 9 & 98-109 & 104 & 3.72 \\
\hline MD8 (ac) & 10 & $102-131$ & 119 & 9.08 \\
\hline SL5 (tu) & 7 & $13-19$ & 17 & 2.07 \\
\hline LV6 (ac) & 10 & $33-40$ & 36 & 2.00 \\
\hline LV7 (ac) & 10 & $38-45$ & 41 & 2.46 \\
\hline LV8 (ac) & 10 & $38-46$ & 41 & 2.32 \\
\hline LV9 (ac) & 10 & $35-41$ & 39 & 1.99 \\
\hline LTS & 9 & $196-242$ & 224 & 13.51 \\
\hline LTS/TL & 9 & $46.8-60.3 \%$ & 54 & 4.90 \\
\hline LTAS & 3 & $74-86$ & 79 & 6.11 \\
\hline
\end{tabular}

$a c$ acicular spine; LTAS lateral terminal accessory spine; LTS lateral terminal spine; $L V$ lateroventral; $M D$ middorsal; $M S W-6$ maximum sternal width, measured on segment 6 in this species; $S$ segment lengths; $S L$ sublateral; $S W-10$ standard width, always measured on segment $10 ; T L$ trunk length; $t u$ tube 
Table 5 Summary of nature and location of sensory spots, glandular cell outlets, tubes, and spines arranged by series in Echinoderes arlis

\begin{tabular}{|c|c|c|c|c|c|c|c|c|c|c|c|}
\hline Position segment & MD & PD & SD & LD & ML & SL & LA & LV & VL & VM & PV \\
\hline 1 & gcol & & ss & ss & ss & & & & gcol & ss & \\
\hline 2 & gco1,ss & & gco2 & ss & ss & gco2 & & & tu & gco1,ss & \\
\hline 3 & gcol & & ss & & ss & & & & & gco1 & \\
\hline 4 & $\mathrm{ac}$ & gco1 & & & & & & & & gcol,ss & \\
\hline 5 & gcol & & ss & & ss & tu & & & & gcol & \\
\hline 6 & $\mathrm{ac}$ & gcol & & & ss & & & $\mathrm{ac}$ & & gcol,ss & \\
\hline 7 & gcol & & ss & & & ss & & $\mathrm{ac}$ & & gcol,ss & \\
\hline 8 & $\mathrm{ac}$ & gco1 & ss & & & tu* & & $\mathrm{ac}$ & & gco $1, \mathrm{ss}$ & \\
\hline 9 & & $\mathrm{gco} 1, \mathrm{ss}$ & ss & & ss & si & & $\mathrm{ac}$ & ss & gcol & \\
\hline 10 & gcol & & Ss & tu & & & & & ss & & gcol \\
\hline 11 & & & ss & & pe $(\widehat{\jmath})$ & & $\operatorname{ltas}(+9)$ & lts & & & \\
\hline
\end{tabular}

$L A$ lateral accessory, $L D$ laterodorsal, $L V$ lateroventral, $M D$ middorsal, $M L$ midlateral, $P D$ paradorsal, $P V$ paraventral, $S D$ subdorsal. $S L$ sublateral, $V L$ ventrolateral, $V M$ ventromedial, $a c$ acicular spine, gco 1 glandular cell outlet type 1, ltas lateral terminal accessory spine, lts lateral terminal spine, pe penile spines, $s i$ sieve plate, $s s$ sensory spot, $t u$ tube (*not present in all specimens); ( + ) female condition of sexually dimorphic characters, ( $)$ male condition of sexually dimorphic characters

\section{Additional new species}

One additional new species of Echinoderes was recorded from stations PS92/31 and PS92/43 (Fig. 1, referred as Echinoderes sp. 1 in Table 1). However, through communication with the kinorhynch research community (Hiroshi Yamasaki, pers. comm.), we learned that the same species had been recorded by K.H. George, B. Neuhaus, and H. Yamasaki from a locality even further north in the Arctic Ocean $\left(86^{\circ} 49^{\prime} 22.80^{\prime \prime} \mathrm{N} 61^{\circ}\right.$ $\left.40^{\prime} 9.60^{\prime \prime} \mathrm{E}\right)$. Hence, rather than describing the new species in parallel, it will be described in a separate contribution in collaboration with the George-Neuhaus-Yamasaki group.

\section{Discussion}

\section{Distribution patterns}

Meiofauna is an important member of the Arctic benthic fauna; however, it remains less studied in Polar regions compared to other benthic dwellers, as macro- or mega-fauna (Piepenburg 2005). Therefore, little is known about biodiversity and distribution of many meiofaunal groups in the Arctic, including Kinorhyncha. As yet, most investigations into the diversity of Arctic kinorhynchs have been carried out in the European and NE American sectors of the Arctic (Higgins and
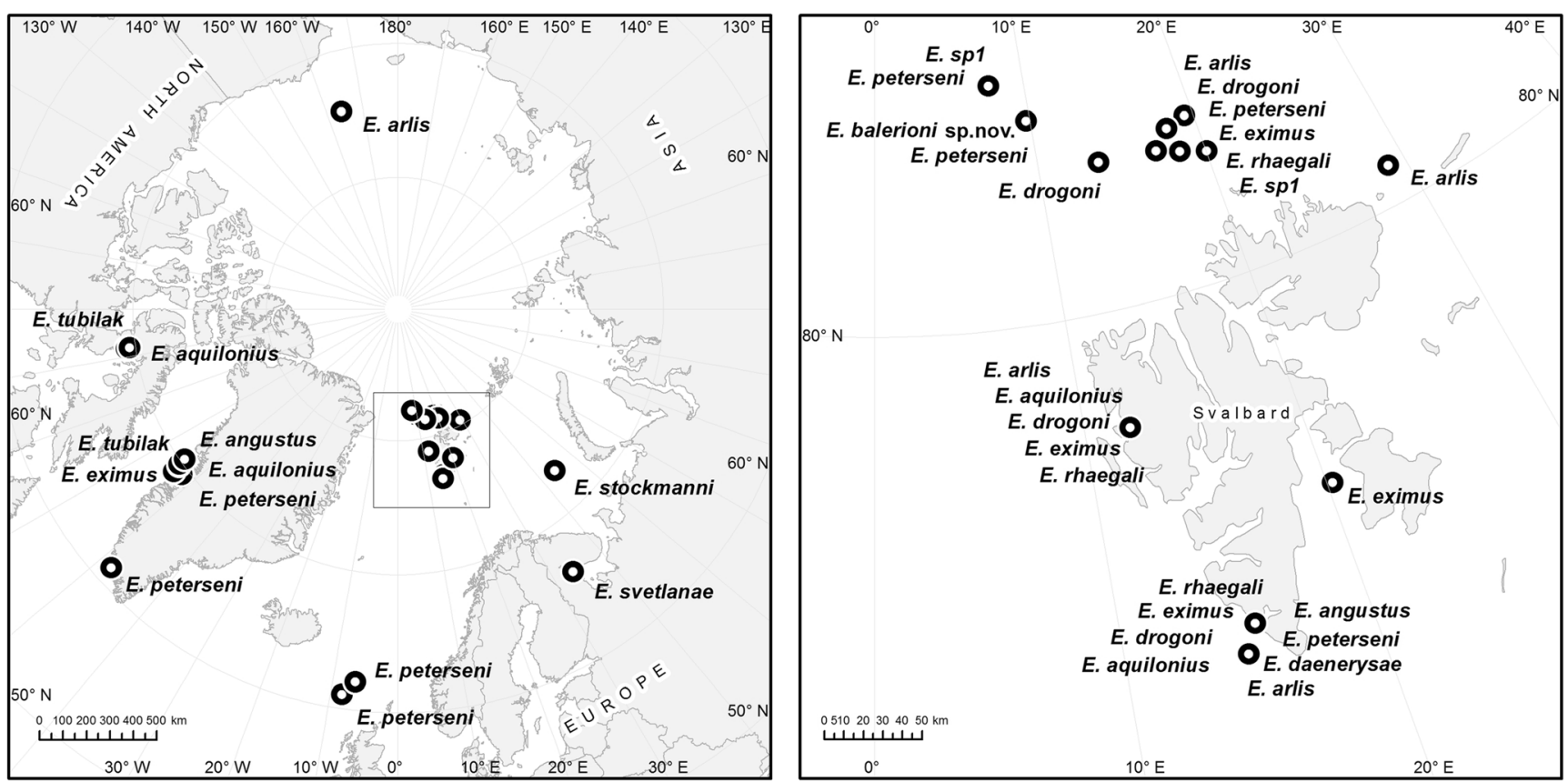

Fig. 7 Map showing the distribution of Echinoderes spp. in Arctic region (left panel) and detailed overview of Echinoderes spp. distribution in Svalbard area (right panel) 
Fig. 8 a Bathymetric and $\mathbf{b}$ latitudinal distribution of Arctic Echinoderes spp.
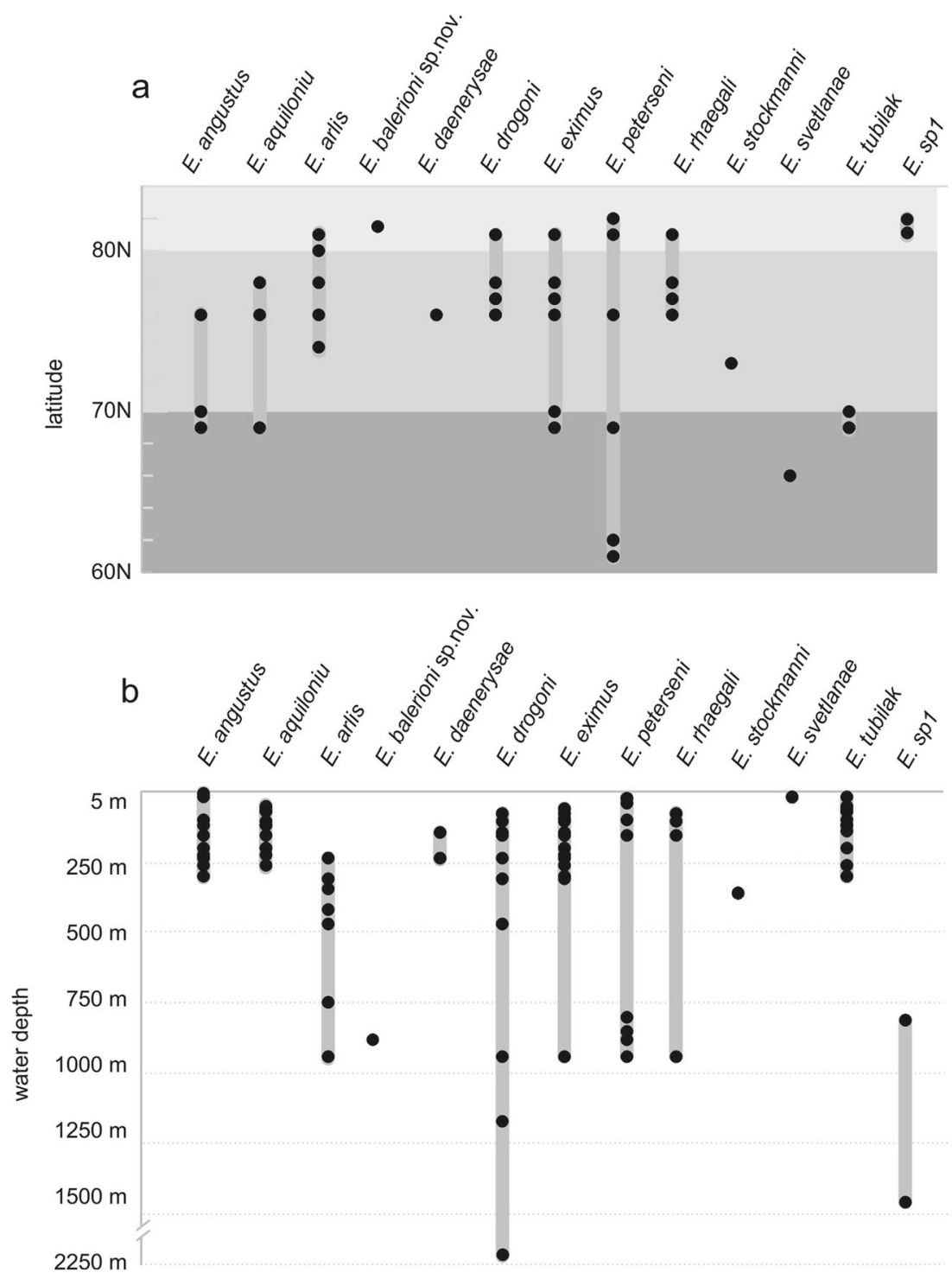

Kristensen 1988; Jørgensen and Kristensen 1991; Willerslev et al. 1996; Winkelmann and Ziemer 1999; Sørensen and Kristensen 2000; Grzelak and Sørensen 2018), but at relatively few localities, thus the sampling of the Arctic shelf remains extremely patchy (Fig. 7). Scarcity of data hampers proper quantification or assessment of regional trends in kinorhynch occurrence; however, our findings suggest that at least some of Echinoderes species might have a circumpolar pattern in their distribution. This is in accordance with the general concept of low biogeographic isolation of the Arctic fauna, since many Arctic benthic organisms are widespread boreal-Arctic species (Piepenburg et al. 2011 and references therein). Our study demonstrates similar trends. Echinoderes aquilonius, E. tubilak and, redescribed in present study, E. arlis, have been recorded in both North American, European, and/or Pacific sectors of the Arctic (Fig 7). In addition, Western Greenland, North Atlantic, Spitsbergen, and the region north off Svalbard share several Echinoderes species (Fig. 7), among which
E. peterseni has the widest latitudinal distribution (Fig. 8a). This species has been noted from Faroe Bank $\left(61^{\circ} \mathrm{N}\right)$, through Spitsbergen $\left(76-78^{\circ} \mathrm{N}\right)$, up to $82^{\circ} 12^{\prime} \mathrm{N}$ latitude, which is the northernmost recording of a kinorhynchs species described to date. Wide and frequent occurrence can be observed for $E$. eximus and E. drogoni. These two species were encountered at most of the investigated stations in present study (Table 1), and both have previously been observed at other localities in the Arctic (Table 6, Figs. 7, 8a). It shows relatively high connectivity between different Arctic regions, despite the presence of physical barriers (oceanic ridges) within the Arctic basins and low degree of endemism in the Arctic. Therefore, it might be expected that species of kinorhynchs spread easily and have wide geographical distributions throughout the Arctic, similar to other taxa such as nematodes or polychaetes (Fonseca and Soltwedel 2007; Bluhm et al. 2011). However, without better taxonomical, molecular, and biogeographical knowledge about arctic kinorhynchs fauna, 
Table 6 Occurrence of Arctic Echinoderes spp. Type localities are boldfaced. If multiple sampling stations are located in close proximity to each other, only one of them is listed. ${ }^{*}$ Location not precise

\begin{tabular}{|c|c|c|c|c|c|}
\hline Species & Region & Locality & Position & Depth & \\
\hline \multirow[t]{11}{*}{ E. angustus } & \multirow[t]{9}{*}{ Greenland, Disko Isl. } & Disko Fjord & $69^{\circ} 29^{\prime} \mathrm{N} 53^{\circ} 57^{\prime} \mathrm{W}$ & $100 \mathrm{~m}$ & Higgins and Kristensen 1988 \\
\hline & & S of Disko Isl. & $69^{\circ} 09^{\prime} \mathrm{N} 53^{\circ} 50$ 'W & $200-250 \mathrm{~m}$ & Higgins and Kristensen 1988 \\
\hline & & Disko Fjord & 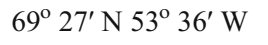 & $6.5 \mathrm{~m}$ & Higgins and Kristensen 1988 \\
\hline & & Disko Fjord & $69^{\circ} 33^{\prime} \mathrm{N} 53^{\circ} 33^{\prime} \mathrm{W}$ & $120 \mathrm{~m}$ & Higgins and Kristensen 1988 \\
\hline & & SE coast of Disko Isl. & $69^{\circ} 27^{\prime} \mathrm{N} 52^{\circ} 32^{\prime} \mathrm{W}$ & $100 \mathrm{~m}$ & Higgins and Kristensen 1988 \\
\hline & & SE coast of Disko Isl. & 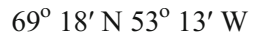 & $225 \mathrm{~m}$ & Higgins and Kristensen 1988 \\
\hline & & S of Disko Isl. & $69^{\circ} 07^{\prime} \mathrm{N} 54^{\circ} 04^{\prime} \mathrm{W}$ & $300 \mathrm{~m}$ & Higgins and Kristensen 1988 \\
\hline & & Mellemfjord & 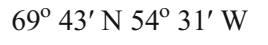 & $18.5 \mathrm{~m}$ & Willerslev et al. 1996 \\
\hline & & NW of Disko Isl. & $70^{\circ} 18^{\prime} \mathrm{N} 54^{\circ} 50^{\prime} \mathrm{W}$ & $262 \mathrm{~m}$ & Willerslev et al. 1996 \\
\hline & \multirow[t]{2}{*}{ Svalbard } & Hornsund, outer part & $76^{\circ} 57^{\prime} \mathrm{N} 15^{\circ} 23^{\prime} \mathrm{E}$ & $155 \mathrm{~m}$ & Grzelak and Sørensen 2018 \\
\hline & & SW of Hornsund & $76^{\circ} 40^{\prime} \mathrm{N} 14^{\circ} 48^{\prime} \mathrm{E}$ & $236 \mathrm{~m}$ & present study \\
\hline \multirow[t]{14}{*}{ E. aquilonius } & \multirow[t]{8}{*}{ Greenland, Disko Isl. } & Disko Fjord & 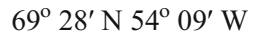 & $200 \mathrm{~m}$ & Higgins and Kristensen 1988 \\
\hline & & Disko Fjord & 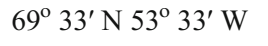 & $120 \mathrm{~m}$ & Higgins and Kristensen 1988 \\
\hline & & Disko Fjord & 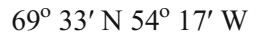 & $200 \mathrm{~m}$ & Higgins and Kristensen 1988 \\
\hline & & SE coast of Disko Isl. & 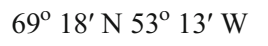 & $225 \mathrm{~m}$ & Higgins and Kristensen 1988 \\
\hline & & S of Disko Isl. & $69^{\circ} 07^{\prime} \mathrm{N} 54^{\circ} 04^{\prime} \mathrm{W}$ & $300 \mathrm{~m}$ & Higgins and Kristensen 1988 \\
\hline & & Mellemfjord & $69^{\circ} 45^{\prime} \mathrm{N} 54^{\circ} 40^{\prime} \mathrm{W}$ & $60 \mathrm{~m}$ & Winkelmann and Ziemer 1999 \\
\hline & & Mellemfjord & $69^{\circ} 46^{\prime} \mathrm{N} 54^{\circ} 37^{\prime} \mathrm{W}$ & $60 \mathrm{~m}$ & Higgins and Kristensen 1988 \\
\hline & & NW of Disko Isl. & $70^{\circ} 18^{\prime} \mathrm{N} 54^{\circ} 50^{\prime} \mathrm{W}$ & $262 \mathrm{~m}$ & Willerslev et al. 1996 \\
\hline & \multirow[t]{2}{*}{ Svalbard } & Hornsund, outer part & $76^{\circ} 57^{\prime} \mathrm{N} 15^{\circ} 23^{\prime} \mathrm{E}$ & $155 \mathrm{~m}$ & Grzelak and Sørensen 2018 \\
\hline & & Kongsfjord, inner part & $78^{\circ} 56^{\prime} \mathrm{N} 12^{\circ} 08^{\prime} \mathrm{E}$ & $105 \mathrm{~m}$ & Grzelak and Sørensen 2018 \\
\hline & \multirow[t]{4}{*}{ Canada, Nunavut } & $\mathrm{S}$ of Igloolik Isl. & $69^{\circ} 20^{\prime} \mathrm{N} 81^{\circ} 43^{\prime} \mathrm{W}$ & $52 \mathrm{~m}$ & Jørgensen and Kristensen 1991 \\
\hline & & S of Igloolik Isl. & $69^{\circ} 18^{\prime} \mathrm{N} 81^{\circ} 37^{\prime} \mathrm{W}$ & $68 \mathrm{~m}$ & Jørgensen and Kristensen 1991 \\
\hline & & S of Igloolik Isl. & $69^{\circ} 20^{\prime} \mathrm{N} 81^{\circ} 37^{\prime} \mathrm{W}$ & $70 \mathrm{~m}$ & Jørgensen and Kristensen 1991 \\
\hline & & $\mathrm{N}$ of Igloolik Isl. & $69^{\circ} 33^{\prime} \mathrm{N} 81^{\circ} 45^{\prime} \mathrm{W}$ & $119 \mathrm{~m}$ & Jørgensen and Kristensen 1991 \\
\hline \multirow[t]{8}{*}{ E. arlis } & \multirow[t]{2}{*}{ Alaska } & NW of Point Barrow & $74^{\circ} 30^{\prime} \mathrm{N} 163^{\circ} 54^{\prime} \mathrm{W}$ & $747 \mathrm{~m}$ & Higgins 1966a \\
\hline & & NW of Point Barrow & $74^{\circ} 48^{\prime} \mathrm{N} 165^{\circ} 36^{\prime} \mathrm{W}$ & $419 \mathrm{~m}$ & Higgins $1966 \mathrm{a}$ \\
\hline & \multirow[t]{6}{*}{ Svalbard } & NE of Nordaustlandet & $80^{\circ} 21^{\prime} \mathrm{N} 29^{\circ} 01^{\prime} \mathrm{E}$ & $345 \mathrm{~m}$ & Adrianov and Malakhov 1999 \\
\hline & & Kongsfjord, central part & $78^{\circ} 59^{\prime} \mathrm{N} 11^{\circ} 43^{\prime} \mathrm{E}$ & $310 \mathrm{~m}$ & Grzelak and Sørensen 2018 \\
\hline & & $\mathrm{N}$ of Svalbard & $81^{\circ} 14^{\prime} \mathrm{N} 18^{\circ} 30^{\prime} \mathrm{E}$ & $470 \mathrm{~m}$ & present study \\
\hline & & $\mathrm{N}$ of Svalbard & $81^{\circ} 31^{\prime} \mathrm{N} 19^{\circ} 27^{\prime} \mathrm{E}$ & $940 \mathrm{~m}$ & present study \\
\hline & & $\mathrm{N}$ of Svalbard & $81^{\circ} 09^{\prime} \mathrm{N} 20^{\circ} 00^{\prime} \mathrm{E}$ & $310 \mathrm{~m}$ & present study \\
\hline & & SW of Hornsund & $76^{\circ} 40^{\prime} \mathrm{N} 14^{\circ} 48^{\prime} \mathrm{E}$ & $236 \mathrm{~m}$ & present study \\
\hline E. balerioni sp. nov. & Svalbard & $\mathrm{N}$ of Svalbard & $81^{\circ} 50^{\prime} \mathrm{N} 09^{\circ} 44^{\prime} \mathrm{E}$ & $880 \mathrm{~m}$ & present study \\
\hline \multirow[t]{2}{*}{ E. daenerysae } & \multirow[t]{2}{*}{ Svalbard } & Hornsund, central part & $76^{\circ} 59^{\prime} \mathrm{N} 15^{\circ} 43^{\prime} \mathrm{E}$ & $145 \mathrm{~m}$ & Grzelak and Sørensen 2018 \\
\hline & & SW of Hornsund & $76^{\circ} 40^{\prime} \mathrm{N} 14^{\circ} 48^{\prime} \mathrm{E}$ & $236 \mathrm{~m}$ & present study \\
\hline \multirow[t]{10}{*}{ E. drogoni } & \multirow[t]{10}{*}{ Svalbard } & Hornsund, inner part & $77^{\circ} 00^{\prime} \mathrm{N} 16^{\circ} 06^{\prime} \mathrm{E}$ & $78 \mathrm{~m}$ & Grzelak and Sørensen 2018 \\
\hline & & Hornsund, central part & $76^{\circ} 59^{\prime} \mathrm{N} 15^{\circ} 43^{\prime} \mathrm{E}$ & $145 \mathrm{~m}$ & Grzelak and Sørensen 2018 \\
\hline & & Hornsund, outer part & $76^{\circ} 57^{\prime} \mathrm{N} 15^{\circ} 23^{\prime} \mathrm{E}$ & $155 \mathrm{~m}$ & Grzelak and Sørensen 2018 \\
\hline & & Kongsfjord, inner part & $78^{\circ} 56^{\prime} \mathrm{N} 12^{\circ} 08^{\prime} \mathrm{E}$ & $105 \mathrm{~m}$ & \\
\hline & & Kongsfjord, central part & $78^{\circ} 59^{\prime} \mathrm{N} 11^{\circ} 43^{\prime} \mathrm{E}$ & $310 \mathrm{~m}$ & Grzelak and Sørensen 2018 \\
\hline & & SW of Hornsund & $76^{\circ} 40^{\prime} \mathrm{N} 14^{\circ} 48^{\prime} \mathrm{E}$ & $236 \mathrm{~m}$ & present study \\
\hline & & $\mathrm{N}$ of Svalbard & $81^{\circ} 14^{\prime} \mathrm{N} 18^{\circ} 30^{\prime} \mathrm{E}$ & $470 \mathrm{~m}$ & present study \\
\hline & & $\mathrm{N}$ of Svalbard & $81^{\circ} 31^{\prime} \mathrm{N} 19^{\circ} 27^{\prime} \mathrm{E}$ & $940 \mathrm{~m}$ & present study \\
\hline & & $\mathrm{N}$ of Svalbard & $81^{\circ} 09^{\prime} \mathrm{N} 20^{\circ} 00^{\prime} \mathrm{E}$ & $310 \mathrm{~m}$ & present study \\
\hline & & $\mathrm{N}$ of Svalbard & $81^{\circ} 20^{\prime} \mathrm{N} 13^{\circ} 38^{\prime} \mathrm{E}$ & $2200 \mathrm{~m}$ & present study \\
\hline \multirow[t]{2}{*}{ E. eximus } & \multirow[t]{2}{*}{ Greenland, Disko Isl. } & S of Disko Isl. & $69^{\circ} 07^{\prime} \mathrm{N} 54^{\circ} 04^{\prime} \mathrm{W}$ & $300 \mathrm{~m}$ & Higgins and Kristensen 1988 \\
\hline & & Disko Fjord & $69^{\circ} 33^{\prime} \mathrm{N} 54^{\circ} 17^{\prime} \mathrm{W}$ & $200 \mathrm{~m}$ & Higgins and Kristensen 1988 \\
\hline
\end{tabular}


Table 6 (continued)

\begin{tabular}{|c|c|c|c|c|c|}
\hline Species & Region & Locality & Position & Depth & \\
\hline & & SE coast of Disko Isl. & $69^{\circ} 18^{\prime} \mathrm{N} 53^{\circ} 13^{\prime} \mathrm{W}$ & $225 \mathrm{~m}$ & Higgins and Kristensen 1988 \\
\hline & & Mellemfjord & $69^{\circ} 45^{\prime} \mathrm{N} 54^{\circ} 40^{\prime} \mathrm{W}$ & $60 \mathrm{~m}$ & Winkelmann and Ziemer 1999 \\
\hline & & Mellemfjord & $69^{\circ} 46^{\prime} \mathrm{N} 54^{\circ} 37^{\prime} \mathrm{W}$ & $60 \mathrm{~m}$ & Winkelmann and Ziemer 1999 \\
\hline & & NW of Disko Isl. & $70^{\circ} 18^{\prime} \mathrm{N} 54^{\circ} 50^{\prime} \mathrm{W}$ & $262 \mathrm{~m}$ & Willerslev et al. 1996 \\
\hline & Svalbard & Hornsund, inner part & $77^{\circ} 00^{\prime} \mathrm{N} 16^{\circ} 06^{\prime} \mathrm{E}$ & $78 \mathrm{~m}$ & Grzelak and Sørensen 2018 \\
\hline & & Hornsund, central part & $76^{\circ} 59^{\prime} \mathrm{N} 15^{\circ} 43^{\prime} \mathrm{E}$ & $145 \mathrm{~m}$ & Grzelak and Sørensen 2018 \\
\hline & & Hornsund, outer part & $76^{\circ} 57^{\prime} \mathrm{N} 15^{\circ} 23^{\prime} \mathrm{E}$ & $155 \mathrm{~m}$ & Grzelak and Sørensen 2018 \\
\hline & & Kongsfjord, inner part & $78^{\circ} 56^{\prime} \mathrm{N} 12^{\circ} 08^{\prime} \mathrm{E}$ & $105 \mathrm{~m}$ & Grzelak and Sørensen 2018 \\
\hline & & Kongsfjord, central part & $78^{\circ} 59^{\prime} \mathrm{N} 11^{\circ} 43^{\prime} \mathrm{E}$ & $310 \mathrm{~m}$ & Grzelak and Sørensen 2018 \\
\hline & & SW of Hornsund & $76^{\circ} 40^{\prime} \mathrm{N} 14^{\circ} 48^{\prime} \mathrm{E}$ & $236 \mathrm{~m}$ & present study \\
\hline & & $\mathrm{N}$ of Svalbard & $81^{\circ} 31^{\prime} \mathrm{N} 19^{\circ} 27^{\prime} \mathrm{E}$ & $940 \mathrm{~m}$ & present study \\
\hline & & Storfjorden & $77^{\circ} 56^{\prime} \mathrm{N} 20^{\circ} 13^{\prime} \mathrm{E}$ & $96 \mathrm{~m}$ & present study \\
\hline \multirow[t]{9}{*}{ E. peterseni } & Greenland, Disko Isl. & Disko Fjord & 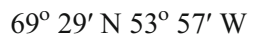 & $100 \mathrm{~m}$ & Higgins and Kristensen 1988 \\
\hline & Greenland, Ivigtut & Ikka Fjord & $61^{\circ} 12^{\prime} \mathrm{N} 48^{\circ} 01^{\prime} \mathrm{W}$ & $24 \mathrm{~m}$ & Sørensen and Kristensen 2000 \\
\hline & Faroe Islands & Faroe Bank & 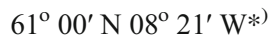 & $?$ & Kristensen 2005 \\
\hline & Faroe Islands & East of Nólsoy & 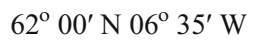 & $41 \mathrm{~m}$ & Sørensen personal collection \\
\hline & Svalbard & Hornsund, outer part & $76^{\circ} 57^{\prime} \mathrm{N} 15^{\circ} 23^{\prime} \mathrm{E}$ & $155 \mathrm{~m}$ & Grzelak and Sørensen 2018 \\
\hline & & $\mathrm{N}$ of Svalbard & $81^{\circ} 18^{\prime} \mathrm{N} 17^{\circ} 8^{\prime} \mathrm{E}$ & $850 \mathrm{~m}$ & present study \\
\hline & & $\mathrm{N}$ of Svalbard & $81^{\circ} 31^{\prime} \mathrm{N} 19^{\circ} 27^{\prime} \mathrm{E}$ & $940 \mathrm{~m}$ & present study \\
\hline & & $\mathrm{N}$ of Svalbard & $82^{\circ} 12^{\prime} \mathrm{N} 07^{\circ} 38^{\prime} \mathrm{E}$ & $800 \mathrm{~m}$ & present study \\
\hline & & $\mathrm{N}$ of Svalbard & $81^{\circ} 50^{\prime} \mathrm{N} 09^{\circ} 44^{\prime} \mathrm{E}$ & $880 \mathrm{~m}$ & present study \\
\hline \multirow[t]{4}{*}{ E. rhaegali } & Svalbard & Hornsund, inner part & $77^{\circ} 00^{\prime} \mathrm{N} 16^{\circ} 06^{\prime} \mathrm{E}$ & $78 \mathrm{~m}$ & Grzelak and Sørensen 2018 \\
\hline & & Hornsund, outer part & $76^{\circ} 57^{\prime} \mathrm{N} 15^{\circ} 23^{\prime} \mathrm{E}$ & $155 \mathrm{~m}$ & Grzelak and Sørensen 2018 \\
\hline & & Kongsfjord, inner part & $78^{\circ} 56^{\prime} \mathrm{N} 12^{\circ} 08^{\prime} \mathrm{E}$ & $105 \mathrm{~m}$ & Grzelak and Sørensen 2018 \\
\hline & & $\mathrm{N}$ of Svalbard & $81^{\circ} 31^{\prime} \mathrm{N} 19^{\circ} 27^{\prime} \mathrm{E}$ & $940 \mathrm{~m}$ & present study \\
\hline E. stockmanni & Russia, Barents Sea & Stockmann Oil Field & $73^{\circ} 00^{\prime} \mathrm{N} 44^{\circ} 00^{\prime} \mathrm{E}$ & $320-340 \mathrm{~m}$ & Adrianov and Malakhov 1999 \\
\hline E. svetlanae & Russia, White Sea & Near White Sea Bio. St. & $66^{\circ} 20^{\prime} \mathrm{N} 33^{\circ} 40^{\prime} \mathrm{E}$ & $15-20 \mathrm{~m}$ & Adrianov and Malakhov 1999 \\
\hline \multirow[t]{12}{*}{ E. tubilak } & Greenland, Disko Isl. & Disko Fjord & $69^{\circ} 28^{\prime} \mathrm{N} 54^{\circ} 09^{\prime} \mathrm{W}$ & $200 \mathrm{~m}$ & Higgins and Kristensen 1988 \\
\hline & & Disko Fjord & 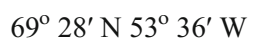 & $140 \mathrm{~m}$ & Higgins and Kristensen 1988 \\
\hline & & Disko Fjord & 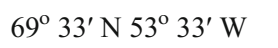 & $120 \mathrm{~m}$ & Higgins and Kristensen 1988 \\
\hline & & SE coast of Disko Isl. & $69^{\circ} 27^{\prime} \mathrm{N} 52^{\circ} 32^{\prime} \mathrm{W}$ & $100 \mathrm{~m}$ & Higgins and Kristensen 1988 \\
\hline & & S of Disko Isl. & $69^{\circ} 07^{\prime} \mathrm{N} 54^{\circ} 04^{\prime} \mathrm{W}$ & $300 \mathrm{~m}$ & Higgins and Kristensen 1988 \\
\hline & & Mellemfjord & $69^{\circ} 43^{\prime} \mathrm{N} 54^{\circ} 31^{\prime} \mathrm{W}$ & $18.5 \mathrm{~m}$ & Willerslev et al. 1996 \\
\hline & & Mellemfjord & $69^{\circ} 45^{\prime} \mathrm{N} 54^{\circ} 40^{\prime} \mathrm{W}$ & $60 \mathrm{~m}$ & Winkelmann and Ziemer 1999 \\
\hline & & NW of Disko Isl. & 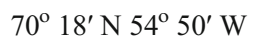 & $262 \mathrm{~m}$ & Willerslev et al. 1996 \\
\hline & Canada, Nunavut & S of Igloolik Isl. & $69^{\circ} 20^{\prime} \mathrm{N} 81^{\circ} 43^{\prime} \mathrm{W}$ & $52 \mathrm{~m}$ & Jørgensen and Kristensen 1991 \\
\hline & & S of Igloolik Isl. & $69^{\circ} 18^{\prime} \mathrm{N} 81^{\circ} 37^{\prime} \mathrm{W}$ & $68 \mathrm{~m}$ & Jørgensen and Kristensen 1991 \\
\hline & & S of Igloolik Isl. & $69^{\circ} 20^{\prime} \mathrm{N} 81^{\circ} 37^{\prime} \mathrm{W}$ & $70 \mathrm{~m}$ & Jørgensen and Kristensen 1991 \\
\hline & & $\mathrm{N}$ of Igloolik Isl. & $69^{\circ} 33^{\prime} \mathrm{N} 81^{\circ} 45^{\prime} \mathrm{W}$ & $119 \mathrm{~m}$ & \\
\hline \multirow[t]{2}{*}{ E. sp. 1} & Svalbard & $\mathrm{N}$ of Svalbard & $81^{\circ} 28^{\prime} \mathrm{N} 18^{\circ} 10^{\prime} \mathrm{E}$ & $1460 \mathrm{~m}$ & present study \\
\hline & & $\mathrm{N}$ of Svalbard & $82^{\circ} 12^{\prime}{\mathrm{N} 07^{\circ}}^{\circ} 38^{\prime} \mathrm{E}$ & $800 \mathrm{~m}$ & present study \\
\hline
\end{tabular}

we can only speculate about the degree of connectivity between Arctic basins and the dispersal mechanisms/abilities of kinorhynchs.

The majority of kinorhynch studies originate from subtidal, shallow $(<300 \mathrm{~m})$ water depths (Neuhaus 2013). The present study presents extensive data regarding the diversity of Echinoderes genus at depths below $300 \mathrm{~m}$. Our results, together with currently available data from other surveys (Table 6), suggest that many of the Arctic Echinoderes species are eurybathic, and present over a wide water-depth range. 
The widest bathymetric occurrence shows $E$. drogoni that spanned a depth range of 78-2200 m (Fig. 8b). Echinoderes arlis, E. eximus, E. peterseni, and E. rhaegali are furthermore covering a relatively large bathymetric range, occurring within a depth range up to $1000 \mathrm{~m}$. It might suggest that bathymetry is not an ecological barrier for those species and does not limit their dispersal along deeper and shallower depths. There are only three species that seem to be confined in their distribution by bathymetry. While others show a wider distribution, E. angustus, E. aquilonius, and E. tubilak were found not deeper than $300 \mathrm{~m}$ water depth (Fig. 8b), regardless the study area. Nevertheless, presented distribution data could be disproven by further investigations. Especially intensive sampling in the deep sea may provide valuable data on biodiversity and biogeography of Echinoderes species.

Conclusions drawn from the distributions ranges of Arctic Echinoderes species are only preliminary and should be carefully assessed, since the low number of studies limits available information of diversity patterns of species. Effect of undersampling probably overwhelmed the real turnover and effect of environmental variables on species distribution patterns.

\section{Tubes}

Out of 33 E. arlis specimens investigated during this study, 18 specimens showed absence of sublateral tubes on segment 8 . E. arlis is therefore the fourth Arctic Echinoderes species that shows variation in the existence of tubes. Sublateral tubes were not observed in any of the type specimens of E. arlis, but if the tubes are due to intraspecific variation, as suggested by observations on the Svalbard population, their absence in the type material might be due to coincidence-especially considering the very limited number of type specimens. Previously, similar intraspecific variation regarding the presence or absence of tubes was observed for $E$. daenerysae, E. eximus, and E. rhaegali (Grzelak and Sørensen 2018). For two species, E. daenerysae and E. rhaegali, variation occurs on segment 2 , with ventrolateral and sublateral tubes, respectively. For E. eximus, variable occurrence of tubes was noted for sublateral tubes on segment 9. Similar to previous observations by Grzelak and Sørensen (2018), presence or absence of tubes in E. arlis occurred apparently randomly, independent of developmental stage or sex. Therefore, we can maintain the explanation proposed by Grzelak and Sørensen (2018), that this morphological variation resulted as naturally occurring genetic changes, affecting alleles, or certain genotypes involved in tube formation (but see Discussion in Grzelak and Sørensen 2018 for more details).

Our results show that intraspecific variation in absence or presence of tubes might be even more frequent among Echinoderes species than previously thought.
Besides the examples in the present contribution and those of Grzelak and Sørensen (2018), a similar variation was also noted within populations of the Baltic species Echinoderes levanderi (Sørensen, unpubl. obs.). Presence or absence of tubes may in certain cases be difficult to confirm with LM only, thus one can speculate if species described before the introduction of SEM in kinorhynch taxonomy may represent even more uncovered examples of this intraspecific variation of tubes. Moreover, it requires a certain amount of specimens to uncover this variation. Low numbers of adult specimens hampers the detailed taxonomic description of new species even today (e.g., E. balerioni sp. nov., see also Table 1), access to a restricted number of specimens is common, particularly for the deep-sea studies sediments. Nevertheless, variation of presence/absence of tubes within populations is an interesting feature and, in our opinion, merits closer attention in future studies.

Acknowledgements We would like to thank Monika Kędra (IOPAN) and Barbara Oleszczuk (IOPAN) for collecting meiofauna samples during the R/V Polarstern (TRANSSIZ expedition PS92 ARKXXIX/1) and R/V Helmer Hanssen (ARCEx expedition) cruises. Klaudia Gregorczyk (IOPAN) is greatly acknowledged for help with meiofauna sorting and Barbara Oleszczuk and Magdalena Łacka (IOPAN) for granulometric analyses. We are also much grateful to Adam Kubicki (Geo Group Wilhelmshaven) for maps preparation. We acknowledge two anonymous referees for their constructive comments of the manuscript.

Funding information Presented material was collected partly during R/V Oceania Arex2013 cruise supported by the statutory activities of the Institute of Oceanology (Sopot, Poland), during R/V Polarstern TRANSSIZ cruise (ARK XXIX/1; PS92), carried out under grant number AWI_PS92_00 and organized by Arctic in Rapid Transition (ART) and partly during R/V Helmer Hanssen ARCEx cruise 2016 ('ARCEx-The research center for ARCTic Petroleum Exploration') funded by the Research Council of Norway (no. 228107), 10 academic and eight industry partners. The study was completed thanks to funding provided by the National Science Centre, Poland (grant no. 2016/20/S/NZ8/00432, 2012/05/B/ST10/01908, and 2015/19/B/NZ8/03945). First author was also supported by the SYNTHESYS Projects (DK-TAF-5319 and DKTAF-6523), which were financed by European Community Research Infrastructure Action under FP7 (http://www.synthesys.info/). Current position of KG is supported by the National Science Centre, Poland, postdoctoral fellowship FUGA (grant no. 2016/20/S/NZ8/00432).

\section{Compliance with ethical standards}

Conflict of interest The authors declare that they have no conflict of interest.

Ethical approval This article does not contain any studies with animals performed by any of the authors.

Sampling and field studies All necessary permits for sampling and observational field studies have been obtained by the authors from the competent authorities and are mentioned in the acknowledgements, if applicable. 
Open Access This article is distributed under the terms of the Creative Commons Attribution 4.0 International License (http:// creativecommons.org/licenses/by/4.0/), which permits unrestricted use, distribution, and reproduction in any medium, provided you give appropriate credit to the original author(s) and the source, provide a link to the Creative Commons license, and indicate if changes were made.

\section{References}

Adrianov AV, Maiorova AS (2015) Pycnophyes abyssorum sp. n. (Kinorhyncha: Homalorhagida), the deepest kinorhynchs species described so far. Deep-Sea Res II 111:49-59

Adrianov AV, Malakhov VV (1999) Cephalorhyncha of the world ocean. KMK Scientific Press, Moscow (in Russian with English translation)

Appeltans W, Ahyong ST, Anderson G, Angel MV, Artois T, Bailly N et al (2012) The magnitude of global marine species diversity. Curr Biol 22:2189-2202

Blott SJ, Pye K (2001) Gradistat: a grain size distribution and statistics package for the analysis of unconsolidated sediments. Earth Surf Process Landf 26:1237-1248

Bluhm BA, Ambrose WG Jr, Bergmann M, Clough LM, Gebruk AV, Hasemann C, Iken K, Klages M, MacDonald IR, Renaud PE, Schewe I, Soltwedel T, Włodarska-Kowalczuk M (2011) Diversity of the arctic deep-sea benthos. Mar Biodivers 41:87-107

Claparède ARE (1863) Zur Kenntnis der Gattung Echinoderes Duj. Beobachtungen über Anatomie und Entwicklungsgeschichte wirbelloser Thiere an der Küste von Normandie angestellt. Leipzig: Verlag von Wilhelm Engelmann, pls XVI-XVII, p 90 92, 119

Fer I, Skogseth R, Haugan PM, Jaccard P (2003) Observations of the Storfjorden overflow. Deep-Sea Res Part I 50:1283-1303

Folk RL, Ward WC (1957) Brazos River bar: a study in the significance of grain size parameters. J Sediment Res 27:3-26

Fonseca G, Soltwedel T (2007) Deep-sea meiobenthic communities underneath the marginal ice zone off Eastern Greenland. Polar Biol 30: 607-618

Grzelak K, Sørensen MV (2018) New species of Echinoderes (Kinorhyncha: Cyclorhagida) from Spitsbergen, with additional information about known Arctic species. Mar Biol Res 14:113-147

Herranz M, Sanchez N, Pardos F, Higgins RP (2014) New Kinorhyncha from Florida coastal waters. Helgol Mar Res 68:59-87

Higgins RP (1966a) Echinoderes arlis, a new kinorhynchs from the Arctic Ocean. Pac Sci 20:518-520

Higgins RP (1966b) Faunistic studies in the Red Sea (in winter, 19611962). Part II. Kinorhynchs from the area of Al-Ghardaqa. Zool Jahrb Syst Oekol Geogr Tiere 93:118-126

Higgins RP (1967) The Kinorhyncha of New-Caledonia. In: Expédition Française sur les Récifs Coralliens de la Nouvelle-Calédonie 2, pp $75-90$

Higgins RP (1983) The Atlantic barrier reef ecosystem at Carrie Bow Cay, Belize, II: Kinorhyncha. Smithson Contrib Mar Sci (18):1-131

Higgins RP (1985) The genus Echinoderes (Kinorhyncha, Cyclorhagida) from the English Channel. J Mar Biol Assoc UK 65:785-800

Higgins RP, Kristensen RM (1988) Kinorhyncha from Disko Island, West Greenland. Smithson Contrib Zool (458):1-56

Huys R, Coomans A (1989) Echinoderes higginsi sp. n. (Kinorhyncha, Cyclorhagida) from the southern North Sea with a key to the genus Echinoderes Claparède. Zool Scr 18:211-221

Jørgensen M, Kristensen RM (1991) Meiofuna investigations from Igloolik, N.W.T. Artic Canada. In: Jørgensen M (ed) Artic biology course 1989 Igloolik Northwest Territories Canada.
Zoological Museum, University of Copenhagen, Copenhagen, pp 61-80

Karling TG (1954) Echinoderes levanderi n.sp. (Kinorhyncha) aus der Ostsee. Ark Zool 7:189-192

Kristensen RM (2005) Fifteen years investigation of the meiofauna of the Faroe Bank (NE Atlantic). Biofar Proc 2005:202-212

Neuhaus B (2013) Kinorhyncha (=Echinodera). In: Schmidt-Rhaesa A (ed) Handbook of Zoology. Gastrotricha, Cycloneuralia and Gnathifera, vol 1. Nematomorpha, Priapulida, Kinorhyncha, Loricifera. De Gruyter, Berlin, pp 181-348

Neves RC, Sørensen MV, Herranz M (2016) First account on kinorhynchs from Portugal, with the description of two new species: Echinoderes lusitanicus and sp. nov. and E. reicherti sp. nov. Mar Biol Res 12:455-470

Pardos F, Higgins RP, Benito J (1998) Two new Echinoderes (Kinorhyncha, Cyclorhagida) including a reevaluation of kinorhynch taxonomic characters. Zool Anz 237:195-208

Piepenburg D (2005) Recent research on Arctic benthos: common notions need to be revised. Polar Biol 28:733-755

Piepenburg D, Archambault P, Ambrose WG, Blanchard AL, Bluhm BA, Carroll ML, Conlan KE, Cusson M, Feder HM, Grebmeier JM et al (2011) Towards a pan- Arctic inventory of the species diversity of the macro- and megabenthic fauna of the Arctic shelf seas. Mar Biodivers 41:51-70

Skogseth R, Haugan PM, Haarpaintner J (2004) Ice and brine production in Storfjorden from four winters of satellite and in situ observations and modeling. J Geophys Res 109:C10008. https://doi.org/10.1029/ 2004JC002384

Sørensen MV (2008) A new kinorhynch genus from the Antarctic deep sea and a new species of Cephalorhyncha from Hawaii (Kinorhyncha: Cyclorhagida: Echinoderidae). Org Divers Evol 8: 230.e1-230.e18

Sørensen MV (2014) First account of echinoderid kinorhynchs from Brazil, with the description of three new species. Mar Biodivers 44:251-274

Sørensen MV, Kristensen RM (2000) Marine Rotifera from Ikka Fjord, SW Greenland. Medd Grønland. Bioscience 51:1-46

Sørensen MV, Landers SC (2014) Two new species of Echinoderes (Kinorhyncha: Cyclorhagida) from the Gulf of Mexico. Front Mar Sci 1: article 8:1-18. https://doi.org/10.3389/fmars.2014.00008

Sørensen MV, Heiner I, Ziemer O (2005) A new species of Echinoderes from Florida (Kinorhyncha: Cyclorhagida). Proc Biol Soc Wash 118:449-508

Sørensen MV, Rho HS, Min W-G, Kim D, Chang CY (2012) An exploration of Echinoderes (Kinorhyncha: Cyclorhagida) in Korean and neighboring waters, with the description of four new species and a redescription of $E$. tchefouensis Lou, 1934. Zootaxa 3368:161-196

Sørensen MV, Dal Zotto M, Rho HS, Herranz M, Sanchez N, Pardos F, Yamasaki H (2015) Phylogeny of Kinorhyncha based on morphology and two molecular loci. PLoS One 10:e0133440. https://doi. org/10.1371/journal.pone. 0133440

Sørensen MV, Herranz M, Landers SC (2016) A new species of Echinoderes (Kinorhyncha: Cyclorhagida) from the Gulf of Mexico, with a redescription of Echinoderes bookhouti Higgins, 1964. Zool Anz 265:48-68

Vincx M (1996) Meiofauna in marine and fresh water sediments. In: Hall GS (ed) Methods for the examination of organismal diversity in soils and sediments. CAB International, University Press, Cambridge

Walczowski W (2013) Frontal structures in the West Spitsbergen current margins. Ocean Sci 9:957-975. https://doi.org/10.5194/os-9-9572013

Willerslev E, Sørensen MV, Hansen AJ (1996) Kinorhyncha from Disko Island, West Greenland-Redescription of Echinoderes tubilak. In: Hansen LB, Kristensen TW, Christiansen MB, Schmidt NM (eds) Arktisk Biologisk Feltkursus, Qeqertarsuaq 1996. Zoological Museum, University of Copenhagen, Copenhagen, pp 127-145 
Winkelmann J, Ziemer O (1999) Distribution and composition of meiofauna with special attention to the Kinorhyncha in the Mellemfjord, Disko Island (West Greenland). Berichte zur Polarforschung 330:170-181

Yamasaki H (2016a) Ryuguderes iejimaensis, a new genus and species of Campyloderidae (Xenosomata: Cyclorhagida: Kinorhyncha) from a submarine cave in the Ryukyu Island, Japan. Zool Anz 265:69-79
Yamasaki H (2016b) Two new Echinoderes species (Echinoderidae, Cyclorhagida, Kinorhyncha) from Nha Trang, Vietnam. Zool Stud 55:32. https://doi.org/10.6620/ZS.2016.55-32

Zelinka C (1894) Über die Organisation von Echinoderes. Verh Dtsch Zool Ges 4:46-49

Zelinka C (1896) Demonstration der Tafeln der EchinoderesMonographie. Verh Dtsch Zool Ges 6:197-199 